\section{NOŠENJE ODGAJATELJA PREDŠKOLSKIH USTANOVA S RIZIČNIM PONAŠANJIMA DJECE ${ }^{4}$}

Izvorni znanstveni članak

Primljeno: listopad, 2017.

Prihvaćeno: studeni, 2018.

UDK 373.211.4:159.97-053.4

DOI 10.3935/ljsr.v25i3.198

\section{Nataša Vlah ${ }^{1}$}

Sveučilište u Rijeci

Učiteljski fakultet

orcid.org/0000-0003-3965-0927

Anja Mirosavljević 2

Sveučilište u Zagrebu

Edukacijsko-rehabilitacijski

fakultet

orcid.org/0000-0003-0060-1036

ma u ponašanju u kasnijoj dobi. Stoga je upravo taj period ključan za prevenciju i rane intervencije. Pri tome su vrtići od posebnog značaja, a kompetentni odgajatelji važan element zaštite kao nositelji brojnih aktivnosti s djecom u predškolskoj ustanovi pa tako i s djecom rizičnih ponašanja. $U$ radu su predstavljeni rezultati kvalitativne analize fokusnih grupa s odgajateljima iz Dječjeg vrtića Rijeka koji donose interpretaciju njihovog doživljaja kompetentnosti i strategija nošenja u radu s takvom djecom, kao i teškoća s kojima se u svakodnevnom radu s rizičnim ponašanjima djece susreću. $U$ tu svrhu primijenjena je tematska analiza prema Clarke i Braun (2013.) kojom su izolirane tri teme: "Čimbenici koji doprinose adekvatnom nošenju s rizičnim ponašanjima djeceu, "Čimbenici koji doprinose neučinkovitom nošenju odgajatelja s rizičnim ponašanjima djece" $i$ »Preporuke za unaprjeđenje rada s djecom s rizičnim ponašanjima". Istaknuta je potreba za implementacijom

1 Izv. prof. dr. sc. Nataša Vlah, socijalna pedagoginja,

e-mail: natasa.vlah@ufri.uniri.hr

2 Doc. dr. sc. Anja Mirosavljević, socijalna pedagoginja,

e-mail: anja.mirosavljevic@erf.hr

Vesna Katić, pedagoginja, e-mail: vesna.katic@ufri.uniri.hr

4 Ovaj rad je financiralo/sufinanciralo Sveučilište u Rijeci projektom 13.10.2.2.03.
Vesna Katić3

Sveučilište u Rijeci

Učiteljski fakultet

orcid.org/0000-0002-9822-1244

Ključne riječi:

odgajatelji, predškolska

djeca; rizična ponašanja,

tematska analiza. 


\section{prevencijskih i ranointerventnih programa u vrtiće te nužnom sustavnom i stručnom podrškom odgajateljima u radu s djecom rizičnih ponašanja.}

\section{UVOD}

Danas više nitko ne dvoji da je promocija mentalnog zdravlja izrazito važna tijekom ranog djetinjstva te je opće prisutna spoznaja o potrebi ranih intervencija kod problema u ponašanju djece do šest godina s ciljem prevencije dugotrajnih negativnih ishoda (Reid, Littlefield i Hammond, 2008.; Boričević Maršanić i sur., 2015. Bogović, Majdančić i Ivezić, 2016.; Brown, Bignall i Ammerman, 2018.). S druge strane, neka ponašanja djeteta mogu biti teška za okolinu, ali predstavljaju samo prolaznu razvojnu fazu u životu djeteta, dok se neka druga zadržavaju, prolongiraju, a možda i intenziviraju, pa zato zahtijevaju stručni pristup. Tako se u literaturi može pronaći podatak o 3-10\% djece u vrtićima koja trajno pokazuju odstupanja u ponašanju u mjeri koja prelazi okvire razvojne faze ili manifestiraju ozbiljne oblike emocionalnih i ponašajnih problema (Jurčević-Lozančić, 2005.; Kuperschmidt, Bryant i Willoughby, 2000., prema Benedict, Horner i Squires, 2007.). Ukratko, recentna literatura govori o evidentnoj prisutnosti rizičnih ponašanja predškolske djece (Kirkhaug i sur., 2012.; Kraljić Babić i Vejmelka, 2015.; Vlah i Ferić, 2017.; Flores i sur., 2018.; Jurčević-Lozančić, 2018.) što utječe i na aktualan interes i razvoj preventivnih i ranointerventnih programa za takve probleme.

Brojna istraživanja donose podatke o različitim oblicima i vrstama problema u ponašanju i posljedicama njihova netretiranja na kasniji život. Dugoročne posljedice mogu uključivati akademski i školski neuspjeh, socijalnu isključenost, zlouporabu sredstava ovisnosti te kršenje zakona u mladosti i odrasloj dobi (Colman i sur., 2007.; Perry i Caroll, 2008.; Shenasa i sur., 2012.; Curtis i sur., 2017.; Teekavanich i sur., 2017.; Uğur, Yürümez i Yılmazer, 2019.). Ako prevencija i rane intervencije nisu omogućene djetetu u najranijoj dobi, longitudinalna istraživanja pokazuju da ta djeca s većom vjerojatnošću slijede put k naprijed spomenutim problemima u ponašanju (Loeber, Farrington i Petechuk, 2003.; Walker, Ramsey i Gresham, 2004.; Zwöorfi i sur., 2016.; lorfino i sur., 2018.). Pritom Reid, Littlefield i Hammond (2008.) kao osobito važno razdoblje navode period rane i predškolske dobi djeteta i to od treće do šeste godine života. Naime, pravovremena detekcija i procjena snaga i potreba djece u najranijoj dobi nužna je kako bi se mogle poduzeti primjerene intervencije (Gettinger, Stoiber, i Koscik, 2008.; Hartas, 2011.; Glascoe, 2015.; Kruizinga, 2015.; Sabriïc, 2017., Koller-Trbović, 1998., 2012.; Koller-Trbović, Mirosavljević i Jeđud Borić, 2017.).

Može se reći da su znanstvene i stručne spoznaje o važnosti prevencije, rane detekcije i intervencija rizičnih ponašanja djece polako, ali sigurno iz teorije, odno-

\section{0 članci}


sno rezultata i zaključaka provedenih istraživanja, postupno prodirale u praksu. To se događalo uglavnom osuvremenjivanjem stručnog rada programa predškolskih ustanova analizirajući i sistematizirajući dosadašnje spoznaje u području prevencije i ranih intervencija vezanih uz zahtjevna ponašanja djece predškolske dobi (Fox i Hemmeter, 2009.; Vlah i Ferić, 2017.). Budući da takva diseminacija znanstveno-stručnih spoznaja u praksu u Hrvatskoj, prema mišljenju autorica ovog rada, još traje, važno je podsjetiti se zašto je važna ranije obrazložena rana detekcija rizičnih ponašanja ${ }^{5}$ i intervencija u odnosu na njih na njih. U tom smislu, Dunlap i sur. (2006.) navode sljedeće:

- Nepravovremene reakcije i intervencije usmjerene k problemima djece dovode do njihovog progrediranja (povećava se vjerojatnost lošeg obrazovnog postignuća, odbacivanja od vršnjaka, mentalnih problema u odrasloj dobi, negativnih utjecaja na obitelj i zajednicu). Stoga problemi zahtijevaju intenzivnije intervencije i resurse.

- lako modeli i »alati« za ranu identifikaciju djece sa zahtjevnim ponašanjima postoje, stvarna detekcija i procjena te djece, kao i usklađene intervencije s procijenjenim potrebama, vrlo su rijetke.

- Kvalitetno vrtićko okruženje i interakcije djeteta s kompetentnim odgajateljem povezane su s manje ponašajnih problema i razvojem socijalnih kompetencija djeteta.

- Intervencije utemeljene na funkcionalnoj procjeni odnosa ponašanja i okruženja djeteta učinkovite su u smanjenju zahtjevnih ponašanja djece.

- Intervencije koje uključuju promjene u obilježjima aktivnosti djeteta te djetetovu socijalnu i fizičku okolinu smanjuju izazovna ponašanja.

- Multidimenzionalne intervencije koje traju duže vrijeme i dosljedno se primjenjuju u različitim djetetovim okruženjima (obitelj, ustanova ranog $\mathrm{i}$

5 Već je i iz dosadašnjeg teksta jasno da se, kada je riječ o problemima u ponašanju djece rane i predškolske dobi, koristi cijeli niz termina i pojmova (npr.zahtjevna ponašanja, izazovna ponašanja, emocionalni i ponašajni problemi, problemi u ponašanju, poremećaji u ponašanju, teškoće u ponašanju, rizična ponašanja...). Međutim, prihvaćanjem Standarda za terminologiju, kriterije i način praćenja pojave poremećaja u ponašanju djece i mladih (Koller Trbović, Žižak i Jeđud Borić, 2011.) nastojalo se ujednačiti terminologiju i razumijevanje ovog pojma. Tako termin problemi u ponašanju predstavlja krovni, opći ili nacionalni pojam za kontinuum ponašanja od onih jednostavnijih, manje težine, opasnosti i štetnosti za sebe i druge, do onih definiranih i/ili sankcioniranih propisima i često težih po posljedicama i potrebama za tretmanom. Taj pojam supsumira ekstremnije oblike tog fenomena u oba smjera: od rizičnih, preko teškoća do poremećaja u ponašanju. Ispravni termini, s obzirom da se radi o djeci rane i predškolske dobi, su rizična ponašanja i teškoće u ponašanju budući da su to prihvaćeni specifični termini za sektor Odgoja i obrazovanja u skladu s navedenim Standardima. Vlah, Štifter i Bijedić (2014.) iz razvojnih razloga intenzivne formacije osobnosti (što je vezano uz motorički, jezični i emocionalno-socijalni razvoj djeteta), u ranoj i predškolskoj životnoj dobi (0-7 godina) govore o rizicima za probleme u ponašanju iako već i iz samog nazivlja proizlazi da su rizici tek rizici, a problematičnog ili rizičnog ponašanja još nema (preventivne mjere) za razliku od rizičnih i teškoća u ponašanju (gdje su vidljive i promjene u ponašanju) pa su u kontekstu ovog rada primjereniji potonji nazivi. 
predškolskog odgoja i obrazovanja itd.) dovode do povećanja u prosocijalnom ponašanju i smanjenju rizičnih ponašanja.

- Uključivanje obitelji u planiranje i implementaciju intervencija doprinosi dugotrajnom smanjenju zahtjevnih ponašanja kod djece.

Ukratko, kao što ističu Fox i Swett (2017.), programi su daleko učinkovitiji i dovode do dugotrajne promjene ponašanja ako su multimodalni (fokusirani na ponašajne, kognitivne, emocionalne i socijalne vještine), primjenjuju se u različitim kontekstima djetetova života (škola, ustanova ranog i predškolskog odgoja i obrazovanja itd.), uključuju važne osobe u djetetovom životu (roditelji i odgajatelji) te se primjenjuju što ranije.

Gledajući kroz povijesnu prizmu, jasno je da se danas već puno zna o prevenciji problema u ponašanju i ranim intervencijama s djecom rizičnih ponašanja. Sredina ustanove ranog i predškolskog odgoja i obrazovanja potencijalni je zaštitni element u zajednici s bitnom ulogom u prevenciji progredirajućih putanja iz ranih rizičnih ponašanja ka kasnijim problemima u ponašanju. Stručnjaci koji rade u takvim ustanovama i svakodnevno oblikuju psihosocijalno okruženje djeteta su, uz roditelje, važni i značajni zaštitni čimbenici. Nažalost, u Hrvatskoj nema dovoljno istraživanja o tome koliko su dosadašnja znanja o prevenciji implementirana u postojeće predškolske ustanove. lako se u ovom radu neće odgovoriti na to pitanje jer je to kompleksan i široko postavljeni istraživački problem, pokušat će se analizirati jedan uži problem koji proizlazi iz navedenog šireg te, prema mišljenju autorica, predstavlja bitan segment u unaprjeđivanju ranih intervencija za djecu rizičnih ponašanja. To je tema kompetencija odgajatelja u vrtiću za kvalitetan odgoj i obrazovanje djece rizičnih ponašanja.

\section{ODGAJATELJI KAO ZAŠTITNI ČIMBENICI U USTANOVI RANOG I PREDŠKOLSKOG ODGOJA I OBRAZOVANJA}

Uključenost djeteta u odgoj i obrazovanje u lokalne ustanove ranog i predškolskog odgoja i obrazovanja može biti njegova zaštita u optimalnom razvoju (Bašić, Ferić Šlehan i Kranželić Tavra, 2007.). Vrtić može pozitivno, odnosno zaštitno utjecati na razvoj djeteta kada su njegovi brojni elementi (poput kompetentnosti odgajatelja, organizacije, kulture i vođenja ustanove, suradnje s roditeljima, didaktičke i prostorne opremljenosti) stručno i znanstveno utemeljeni ${ }^{6}$. Od ovog širokog dijapazona elemenata zaštitnih utjecaja na razvoj djeteta u vrtiću upravo

Isto tako, izostanak stručnog rada u odgoju i obrazovanju djeteta rane i predškolske dobi utemeljenog na znanstvenim dokazima i sjasnom teorijskom podlogom može predstavljati rizik za njegov nepovoljan bio-psiho-socijalni razvoj.

\section{2 članci}


je odgajatelj u fokusu interesa ovoga rada. Odgajateljeva kompetentnost, njegova znanja, vještine, stavovi, vrijednosti i navike, (Slunjski, 2015.; Williford i sur., 2017.; Vlah i Ferić, 2017.) kao i druge (posebice osobne) karakteristike i implicitne teorije (Vlah i Tatalović-Vorkapić, 2017.), izrazito su važne za postignuća u dječjem razvoju i prevenciju rizičnih ponašanja u budućnosti.

Odgajateljska uloga nije laka jer u svakodnevnom radu odgajatelji imaju brojne uloge i zadatke. Odgovorni su za cjeloviti razvoj djeteta (Ministarstvo znanosti, obrazovanja i sporta, 2014.), a vezano uz temu ovog rada, naglasak je na njihovoj odgovornosti za socijalno-emocionalni razvoj i učenje djeteta. U tom smislu, poznato je kako se rizična ponašanja pojavljuju ako nisu zadovoljene djetetove socijalno-emocionalne potrebe (McCabe i Frede, 2007.). Slee (2003.) naglašava kako je važno da odgajatelji promišljaju i reflektiraju o svojim stavovima i uvjerenjima kako bi pomogli djeci s teškoćama u ponašanju (ali i svoj djeci) da budu socijalno kompetentnija. Isti autor zaključuje kako je odgajateljeva uloga kreirati pozitivne odnose s vršnjacima i/ili razvijati socijalnu kompetentnost djece, planirati odgojno-obrazovni rad s djecom i svojom kompetentnošću/stručnošću "predstavljati« zaštitu, a ne rizik u pozitivnom razvoju. Nadalje, kada je riječ o odgajatelju kao zaštitnom činitelju u odgojno-obrazovnoj skupini u vrtiću, Williford i sur. (2017.) ističu važnost interakcija odgajatelja i djece rizičnih ponašanja jer upravo o kvaliteti tih interakcija može ovisiti i procjena djetetovih rizičnih ponašanja. Kvaliteta interakcija i procjena rizičnih ponašanja uvelike ovise o prethodnom obrazovanju odgajatelja kao i završenim dodatnim edukacijama (Male, 2003.), odnosno o njegovim kompetencijama za stručni rad. Slično zaključuju i Jolivette i Steed (2010.) pa navode kako odgajatelji moraju usvojiti znanja i vještine o različitim oblicima upravljanja odgojnom skupinom, grupnim i individualnim pristupima, brojnim metodama i tehnikama interveniranja kako bi smanjili rizična ponašanja i poticali socijalni razvoj djece. Upravo recentno istraživanje Jurčević-Lozančić (2018.), provedeno u hrvatskom kulturološkom kontekstu predškolskih ustanova, potvrđuje o rastućim potrebama usvajanja novih profesionalnih kompetencija odgajatelja u vrtićima koje bi adekvatno odgovorile na potrebe rješavanja problema odgoja i obrazovanja djece s teškoćama.

Osim profesionalnih kompetencija dobivenih obrazovanjem, i osobne karakteristike odgajatelja (njihova općenita filozofija razumijevanja djeteta i ranog djetinjstva, pogleda na dijete i način njihova poučavanja i odgoja, odnosno implicitna pedagogija), itekako utječu na način nošenja s rizičnim ponašanjima (Tatalović Vorkapić, 2015.; Vlah i Tatalović Vorkapić, 2017.). Pri tome je veoma važno i to da način na koji odgajatelji doživljavaju djecu, njihove obitelji i svoju ulogu određuje razinu anksioznosti odgajatelja u nošenju s teškim ponašanjima djeteta Roffey (2005.). 
U kontekstu istraživanja ove teme u Hrvatskoj, Bašić (2008.) na temelju istraživanja u nekoliko istarskih gradova zaključuje kako su samopercepcija i opća učinkovitost odgajatelja u predškolskim ustanovama visoke te da se tek 5-8\% odgajateljica procjenjuje nekompetentnima u svom svakodnevnom radu, a Vlah, Smojver-Ažić i Dorčić-Martinac (2017.) utvrdile su da je samoprocijenjena učinkovitost odgajatelja u Dječjem vrtiću Rijeka značajan prediktor u detektiranju rizičnih ponašanja kod djece rane dobi u programu dječjih jaslica.

Upravo ova usmjerenost na odgajatelja kao ključnog čimbenika, koji je stručno osposobljen za vođenje odgojno-obrazovnog procesa u koji je uključeno i dijete rizičnog ponašanja, upućuje na bolje razumijevanje njegove osposobljenosti za kvalitetnu prevenciju i rane intervencije za djecu rizičnih ponašanja. Naime, provedba odgojno-obrazovnog procesa podrazumijeva da zajedno s drugim stručnjacima prati, procjenjuje i planira odgojno-obrazovni rad (Slunjski, 2015.). Praćenje i procjenjivanje predstavljaju temelj za planiranje stručnog rada jer omogućuju uvid u vlastite postupke, ali i dobro upoznavanje i razumijevanje svakog djeteta posebno (djetetov napredak u razvoju i učenju te događanja u neposrednom okruženju djeteta i zajednici u cjelini). Smjernice Nacionalnog kurikuluma za rani i predškolski odgoj i obrazovanje (Ministarstvo znanosti, obrazovanja i sporta, 2014.) upućuju na to da je pri planiranju važno integrirati razvojno primjerena očekivanja za svako dijete, zahtjeve mogućnosti za razvoj kreativnosti, istraživanja, uz uvažavanje interesa i potreba svakog djeteta, kao i grupe djece.

U skladu s navedenim, ovo eksplorativno istraživanje nastoji dočarati perspektivu odgajatelja o doživljaju i iskustvu nošenja s rizičnim ponašanjima djece u svakodnevnom radu. Već je i iz ranijeg teksta jasno da se odgajatelj u ovom istraživanju doživljava kao ključna figura i nositelj većine neposrednih aktivnosti s djecom i roditeljima u predškolskoj ustanovi. Upoznavanje perspektive odgajatelja važno je i iz razloga što predškolske ustanove teže postati mjesta na »kojima se konstruira i sukonstruira znanje» (Miljak, 2009::157). Brunerovim (2000.) riječima rečeno - na taj se način gradi gradbena teorija primjenjiva u praksi.

Nastavno na uvodno navedeno, definirana su tri istraživačka pitanja:

1. Kako se odgajatelji suočavaju s rizičnim ponašanjima djece u svom radu?

2. Kako doživljavaju vlastitu kompetentnost za rad s djecom koja manifestiraju rizična ponašanja u vrtićkom okruženju?

3. Kakve preporuke za unaprjeđivanje kvalitete stručnog rada s rizičnim ponašanjima djece imaju?

Tekst koji slijedi nudi odgovore na postavljena pitanja s ciljem osvjetljavanja strategija i načina suočavanja odgajatelja s rizičnim ponašanjima djece u dječjim vrtićima u Rijeci.

\section{4 Članci}




\section{METODE ISTRAŽIVANJA}

Istraživanje prikazano u ovom radu dio je kompleksnijeg mixed-method istraživanja u okviru projekta pod nazivom »Razine rizika za probleme u ponašanju djece rane razvojne dobi i stručne intervencije u Rijeci« čija je krajnja svrha izrada modela ranih intervencija u gradu Rijeci kroz osnivanje Centra za rane intervencije.

U ovom radu bit će predstavljeni rezultati kvalitativnog dijela istraživanja koje je provedeno tijekom 2015. godine u suradnji s Dječjim vrtićem Rijeka.

\section{OPIS SUDIONIKA}

Istraživanje je provedeno u Dječjem vrtiću Rijeka. U trenutku prikupljanja podataka, rad u Dječjem vrtiću Rijeka, čiji je osnivač grad Rijeka ${ }^{7}$ bio je organiziran u pet centara predškolskog odgoja (CPO: Sušak, Maestral, Potok, Turnić i Zamet). Svaki centar predškolskog odgoja čini nekoliko podcentara predškolskog odgoja (PPO) ili kuća u funkciji vrtića (ukupno 31 podcentar) pa je poštujući kriterij proporcionalnosti za svaki CPO u istraživanju planirano sudjelovanje po dva odgajatelja iz PPO-a unutar pet CPO-a (u pet fokusnih grupa). Svi sudionici trebali su zadovoljiti kriterij relevantnosti uzorka, a posebno sudionika bogatih informacijama, kako ga opisuje Patton (2002.). Dodatni kriterij izbora sudionika postavljen je s obzirom na duljinu radnoga iskustva u predškolskoj ustanovi (najmanje tri godine radnog iskustva).

Konačan uzorak sudionika činilo je 28 žena i jedan muškarac. Dob sudionika kretala se od 28 do 60 godina. Radno iskustvo, odnosno formalni radni staž sudionika kretao se u rasponu od 4 do 41 godine. $S$ obzirom da su zaposleni u različitim CPO-ima, tijekom svog rada radili su (ili rade) u odgojno-obrazovnim skupinama u kojima se provode različite vrste programa (npr. redoviti programi, posebni i specijalizirani programi za djecu s teškoćama poput motoričkih oštećenja, smanjenih intelektualnih sposobnosti i poremećaja iz spektra autizma $\left.{ }^{8}\right)$. U Tablici 1. prikazan je broj sudionika fokusnih grupa po CPO-ima.

\footnotetext{
7 Čitav kompleks godišnje zbrinjava preko 3000 djece rane i predškolske dobi i zapošljava više od 370 djelatnika u realizaciji više vrsta programa (redoviti, obogaćeni, posebni i kraći program). Uz redovite programe, provode se posebni i specijalizirani programi kao što su programi za djecu s teškoćama, za darovitu djecu rane i predškolske dobi, za djecu pripadnika nacionalnih manjina, programi predškole, te programi ranog učenja stranih jezika i drugi programi umjetničkog, kulturnog, vjerskog i sportskog sadržaja. Odgojno-obrazovni rad temelji se na humanističko-razvojnoj koncepciji, a temeljno ishodište svih programa čini Nacionalni kurikulum za rani i predškolski odgoj i obrazovanje (2014.).

8 https://www.rivrtici.hr/posebni-program
} 
Tablica 1. Prikaz broja sudionika fokusnih grupa po CPO-ima Dječjeg vrtića Rijeka

\begin{tabular}{lccccc}
\hline & CPO Maestral & CPO Sušak & CPO Turnić & CPO Zamet & CPO Potok \\
\hline Broj sudionika & 6 & 6 & 6 & 4 & 7 \\
\hline
\end{tabular}

\section{METODE PRIKUPLJANJA I OBRADE PODATAKA}

Podaci su prikupljani metodom razgovora u fokusnim grupama. U pripremi terenskog rada konzultirani su pojedini stručnjaci iz dječjih vrtića imenovani kao kontakt osobe od strane ravnatelja. Inicijalni sastanak (na kojem je predstavljen projekt te definirana međusobna očekivanja i hodogram rada) održan je s pedagozima Dječjeg vrtića Rijeka budući da su upravo oni odgovorni za organizaciju i osiguranje uvjeta realizacije odgojno-obrazovnog procesa.

$\mathrm{U}$ istraživanju smo slijedili tri ključne faze u primjeni ove metode, kako ih navode Milas (2005.) i Patton (2002.): 1) planiranje (izrada vodiča za fokusne grupe kreiran od autorica rada, izbor sudionika, dogovor oko mjesta i vremena održavanja fokusnih grupa), 2) provedba (od strane dva istraživača komoderatora fokusnih grupa pri čemu su sve fokusne skupine provele članice istraživačkog tima u prostoru pojedinog vrtića ovisno o CPO-u. Svaka fokusna skupina snimana je audio-vizualno i poslije doslovno prepisivana) i 3) analiza podataka (za obradu podataka korištena je induktivna tematska analiza (Braun i Clarke, 2006., 2012.; Clarke i Braun, 2013.) u NVivo 10 računalnom programu.

\section{Osvrt na vjerodostojnost, dosljednost i prenosivost}

Braun i Clarke (2006.) navode »check« listu s 15 stavki za procjenu kvalitete provedene tematske analize koja je korištena i u ovom istraživanju.

No, unatoč negativnom stavu i polemikama Braun i Clarke (2006.) o validacijskim strategijama u kvalitativnom pristupu, priklonili smo se Creswellu (2013.) i Vučković Juroš (2011.) koji navode da postoji šest mogućih strategija s preporukom da minimalno dvije budu korištene u svakom kvalitativnom istraživanju. Ukratko ćemo se osvrnuti na primjerenost donesenih istraživačkih odluka i primijenjenih validacijskih strategija prema gore navedenim autorima.

Izvori podataka triangulirani su tako da su podaci prikupljeni od odgajatelja, ali i stručnih suradnika u Dječjem vrtiću Rijeka (u jednoj fokusnoj grupi) koji su korišteni $i$ komparirani tijekom procesa analize kako bi se istražio isti fenomen ili teme.

lako se vanjska revizija (eng. external audit) i međukodersko slaganje (Guest, MacQueen i Namey, 2012.) nije moglo provjeriti zbog nedostatka dodatnih istraži-

\section{6 članci}


vača »kodera«, u razdoblju od mjesec i pol dana dijelove fokusnih grupa, autorica koja je radila obradu, kodirala je ponovno i usporedila s prvotnim kodiranjem.

Rezultati analize podataka provjereni su s dva sudionika istraživanja koji su pročitali rezultate i komentirali ih s ciljem provjere interpretacije podataka.

Prikupljanje podataka provodilo je više istraživača što ide u prilog vjerodostojnosti. U odnosu na poziciju istraživača, važno je spomenuti činjenicu da nijedna od autorica rada nije uključena u neposredan praktični rad s djecom u Dječjem vrtiću Rijeka. Nadalje, tijekom obrade podataka i donošenja zaključaka, vođene su i međusobno diskutirane teorijske ili analitičke bilješke.

U kontekstu prenosivosti (Horsburgh, 2003.; Lewis i Ritchie; 2003.; Ryan i Bernard, 2000., prema Falk i Guenther, 2007.; Creswell, 2013.) tipično za kvalitativna istraživanja, ne može se govoriti o generalizaciji koja bi omogućila zaključivanje o cijeloj populaciji iz koje je uzorak izveden. Unatoč tome, određene teorijske implikacije kao i sličnosti dobivenih nalaza s dosadašnjom znanstveno-stručnom literaturom, evidentne su. Stoga je, unatoč namjernom uzorku i svim njegovim ograničenjima, opravdano vjerovati i da se zaključci mogu prenijeti na populaciju odgajatelja, barem za Rijeku, a u skladu s navedenim koristiti za daljnje znanstveno, ali i praktično unaprjeđenje rada.

\section{Etički aspekti istraživanja}

U ovom su se istraživanju poštovale sve smjernice važećih etičkih kodeksa i zakona u Republici Hrvatskoj. Ukratko, glavna etička pitanja odnosila su se na davanje pisane informirane dobrovoljne suglasnosti sudionika za sudjelovanje $u$ istraživanju, zaštitu povjerljivosti i privatnosti sudionika, zaštitu dobrobiti sudionika tijekom prikupljanja podataka, odnosno provedbu fokusnih grupi u povjerljivom i sigurnom okruženju. Osim toga, istraživanje je provedeno od istraživačica koje imaju kompetencije pomažućih profesija/socijalne pedagogije i pedagogije (npr. vođenje intervjua, stvaranje ugodne interakcije, vođenje računa o načinu komunikacije sa sudionicima i njihovim potrebama). Nakon prijepisa fokusnih grupa, isti su poslani sudionicima na autorizaciju, a rezultati istraživanja bit će predstavljeni sudionicima s ciljem diseminacije stečenih spoznaja u praksu.

\section{REZULTATI ANALIZE}

Induktivnom tematskom analizom transkripta razgovora u fokusnim grupama identificirane su tri teme: „Čimbenici koji doprinose adekvatnom nošenju odgajatelja s rizičnim ponašanjima djece«, »Čimbenici koji doprinose neučinkovitom nošenju 
odgajatelja s rizičnim ponašanjima djece« $\mathbf{i}$ »Preporuke za unaprjeđenje rada $s$ djecom rizičnih ponašanja«.

\section{1. tema »Čimbenici koji doprinose adekvatnom nošenju odgajatelja s rizičnim ponašanjima djece»}

Prva tema kreće od svijesti sudionika o važnosti vlastite uloge odgajatelja u nošenju i radu s djecom rizičnih ponašanja pa tako pojašnjavaju zašto je tomu tako i zaključuju da važnost uloge počiva na nekoliko ključnih razloga, a to je neposredan stalni kontakt s djecom zbog čega su upravo oni ti koji najbolje poznaju dijete i imaju mnogo informacija o djetetu i njegovim ponašanjima, a s druge, zato jer je odgajatelj i zbog svoje profesionalne uloge dužan intervenirati.

Ključno polazište u izgradnji kompetencija odgajatelja za ovu zahtjevnu ulogu jest pozitivan stav prema djeci i poslu općenito, ali i specifičnije - prema djeci s rizičnim ponašanjima (što se ogleda u, primjerice, zainteresiranosti za rad, prihvaćanju i uvažavanju djeteta u riziku i njegovih potreba i sl.) kao i prema njihovim roditeljima (iskazuju razumijevanje za roditelje i uvažavaju, odnosno naglašavaju važnost njihove uloge za adekvatnu prevenciju i rane intervencije kako ponašanja ne bi progredirala).

Na razini kompetencija, moguće je zaključiti da odgajatelji uglavnom posjeduju znanja i njeguju adekvatan vrijednosni sustav, ali manje posjeduju vještine za suočavanje $s$ rizičnim ponašanjima i interveniranje. $U$ tom smislu, evidentna je njihova svijest i/ili poznavanje suvremenih pristupa i načela rada s djecom u riziku kao i znanja o značaju partnerstva i/ili spremnost na timski rad i suradnju s kolegama, članovima stručnog tima, roditeljima te stručnjacima zaposlenim u servisima u lokalnoj zajednici. Na razini vještina, izvještavaju o vlastitim kompetencijama za detekciju rizičnih ponašanja, korištenju nekih učinkovitih intervencija prema djeci u riziku, ali i vršnjacima u odgojnoj skupini. Nadalje, govore o vještini informiranja roditelja (ali podrške i savjetovanja ne) te navode i intervencije vezane uz vlastitu samokontrolu.

Na razini kompetencija u području profesionalnog razvoja, odgajatelji govore o vlastitoj svjesnosti o nužnosti rada na sebi kao i važnosti cjeloživotnog obrazovanja.

Detaljan opis teme slijedi u daljnjem tekstu kroz kategorije i kodove (pisane kurzivom). Ovu temu, dakle, čini osam kategorija: »svijest o važnosti vlastite uloge odgajatelja u nošenju s rizičnim ponašanjima djece«, »pozitivni stavovi prema radu s djecom i afinitet za rad s djecom rizičnih ponašanja«, »razumijevanje i uvažavanje roditelja《, »kompetentnost za prepoznavanje rizičnih ponašanja《, »svijest o važnosti suvremenih pristupa i načela u radu s djecom rizičnih ponašanja«, »svijest o važnosti timskog rada/ suradnje za rješavanje problema i spremnost odgajatelja na surad-

\section{8 članci}


nju«, »učinkovite intervencije« $\mathrm{i}$ »svjesnost o nužnosti rada na sebi i cjeloživotnog obrazovanja odgajatelja«.

U skladu s navedenim, prva tema »Čimbenici koji doprinose adekvatnom nošenju odgajatelja s rizičnim ponašanjima djece« kreće od kategorije nazvane "svijest sudionika o važnosti vlastite uloge u nošenju s rizičnim ponašanjima djece«. Tome doprinosi činjenica da su upravo odgajatelji ti koji su u »stalnom neposrednom kontaktu s djecom « zbog čega i »najbolje poznaju djecu« u vrtićkom okruženju te su "važan izvor informacija o djetetu«. Stoga odgajatelji moraju biti aktivni jer je, prema iskazu sudionika, njihova profesionalna »dužnost reagirati i intervenirati«, odnosno znati prepoznati, razumjeti i pravilno odgovoriti na mnoge kompleksne i suptilne odgojne izazove i ponašanja djece.

Nadalje, analizom je identificirano da velik dio odgajatelja njeguje "pozitivne stavove prema radu s djecom kao i afinitet za rad s djecom rizičnih ponašanja« što je zasigurno osnovna premisa i preduvjet primjerenih i učinkovitih intervencija. Ta se kategorija, sumarno gledajući, sastoji od kodova: »ljubav prema poslu i djeci«, "zainteresiranost za rad i djecu rizičnih ponašanja", "prihvaćanje djeteta s rizičnim ponašanjem«, »uvažavanje posebnosti svakog djeteta«i »zadovoljstvo pozitivnim pomacima kod djeteta s rizičnim ponašanjima (uočavaju i najmanje pomake, iskazuju ponos i sreću zbog promjena u ponašanju). Ukratko, sudionici govore o vlastitim pozitivnim stavovima prema poslu i djeci, posvećenosti poslu, usmjerenosti na dijete (dijete je u središtu, odnosno od djeteta kreću u promišljanju vlastitog rada), vlastitoj ulozi, ali dvoje (što ćemo kasnije vidjeti) oko kompetencija za procjenu i interveniranje. Osim toga, motivirani su za rad.

Osim ove pozitivne slike sve djece pa i one u riziku, dio njih spominje i »razumijevanje i uvažavanje roditelja (i obiteljske situacije) djece s rizičnim ponašanjima«, odnosno: »uvažavanje uloge obiteljik, »uzimanje u obzir specifičnosti svake obiteljik (osjetljivost, empatija i razumijevanje za postojeće obiteljske probleme djece) te "suradljive i zainteresirane roditelje« (koji su, doduše, kako navode, rijetkost) koji im svakako olakšavaju rad s djecom rizičnih ponašanja.

Na razini kompetencija, dio odgajatelja izvještava o vlastitoj »kompetentnosti za prepoznavanje rizičnih ponašanja« čemu u prilog ide doživljaj i da su upravo odgajatelji »prva karika u lancu reakcija i odgovora na djetetovo ponašanje« jer od njih »sve počinje«, zatim shvaćanje »detekcije rizičnih ponašanja kao prvog koraka za rješavanje problema«, »senzibiliziranost odgajatelja za trijažu, probir i identifikaciju rizičnih ponašanja« (pa pod tim vidom sudionici navode neke od »metoda i tehnika koje koriste u radu « poput narativnih bilješki, funkcionalnog praćenja ponašanja, metode opažanja i sl.). Osim toga, izvještavaju i o vlastitoj »sposobnosti za rano i pravovremeno detektiranje rizičnih ponašanja«. Općenito gledajući, stariji odgajatelji procjenjuju da danas postoji »veći senzibilitet za detekciju rizičnih ponašanja nego ranije«. 
»Svijest o važnosti suvremenih pristupa i načela u radu $s$ djecom rizičnih ponašanja« iduća je kategorija koja čini ovu temu, a svjedoči o poznavanju vrijednosnih okvira kvalitetnog rada s djecom u riziku od strane odgajatelja. Tako se sudionici istraživanja specifično osvrću na "pozitivan pristup djeci u riziku (posebice vjeru u dijete i mogućnost napretka, usmjerenost i naglašavanje jakosti, snaga i dobrih strana djeteta, optimizam) $i$ »pozitivan autoritet", »sofisticiran i nježni pristup za internalizirana ponašanja«, »individualan« $i$ »individualizirani pristup (pri čemu posebno naglašavaju da sadašnji grupni pristup, u kombinaciji s brojnim teškoćama s kojima se u radu odgajatelji susreću, nije adekvatan za eksternalizirana rizična ponašanja). Usto, govore i o važnosti: »prepoznavanja potreba svakog djeteta«, »rane i pravodobne detekcije, procjene i intervencije«, »usklađenosti intervencija s potrebama djeteta«. Nadalje, izvještavaju i o "značaju stvaranja kvalitetnog odnosa odgajatelja s djetetom« te posebice naglašavaju »važnost timskog pristupa planiranju i programiranju intervencija«.

Zbog izuzetnog značaja koje sudionici istraživanja pridaju načelu uzajamne suradnje i timskog pristupa djeci s rizičnim ponašanjima, kao posebna kategorija izdvojena je ona nazvana »svijest o važnosti timskog rada/suradnje za rješavanje problema i spremnost odgajatelja na suradnju«. U izjavama sudionika bilo je moguće prepoznati da kvalitetnu komunikaciju i suradnju roditelja, stručnjaka, odgajatelja i djeteta doživljavaju kao ključne elemente kompetentnog i učinkovitog nošenja s rizičnim ponašanjima. Kategorija se, dakle, kako i njen sam naziv kaže, bavi važnošću suradnje roditelja, odgajatelja i članova stručnog tima u vrtiću za uspješno detektiranje, procjenu, planiranje i provedbu intervencija. Tako kodovi oslikavaju svijest odgajatelja o "podjednakoj važnosti uloga«, doprinosa i odgovornosti svih stručnjaka (pa i njih samih) uključenih u život djeteta i roditelja za rješavanje problema koje dijete manifestira pri čemu najvažnijim procjenjuju, već spomenuti, »timski rad« kao osnovno načelo ili princip u pristupanju i radu s djetetom i roditeljima.

No, unatoč velikoj važnosti koju daju roditeljima u procesu detekcije, procjene i nošenja s rizičnim ponašanjima kao i »suradnji s njima«, često ih doživljavaju »kao izvor problema«. U okviru ove kategorije naglašavaju »važnost suradnje s roditeljima« (gradnje odnosa i povjerenja s roditeljima) s ciljem rješavanja problema/nepoželjnih/rizičnih ponašanja djece tim više što su itekako svjesni da »njihova odgajateljska postignuća uvelike »ovise o roditeljskim ponašanjima«. No, rad s roditeljima za odgajatelje je težak, a ono što je posebno problematično jesu brojni »problemi s kojima se odgajatelji suočavaju u radu s roditeljima« (o čemu će biti riječi kasnije u tekstu u okviru čimbenika koji otežavaju rad s djecom rizičnih ponašanja).

Nadalje, »suradnja s članovima stručnog tima i kolegama odgajateljima«, odnosno stručna podrška i pomoć u radu s djecom rizičnih ponašanja za sve sudionike

\section{0 članci}


istraživanja izrazito je važna i o tome eksplicitno govore. Pod tim vidom navode kako kod ozbiljne sumnje na rizična ponašanja uglavnom uključuju stručni tim ili nekog od članova (najčešće psihologa ili rehabilitatora) kao prvi oslonac u radu, a za sveukupno kvalitetan rad u odgojnoj skupini tu pomoć i njihove smjernice procjenjuju neophodno potrebnim. Osim toga, neki sudionici navode kako »tim uključuju u kasnijim fazama«, kada procijene da sami više ne mogu. Drugim riječima, intenzitet manifestiranih rizičnih ponašanja djeteta prati i razina uključenosti drugih stručnjaka i roditelja. Nadalje, konzultacije i razmjenu informacija s kolegom odgajateljem procjenjuju izuzetno korisnim tako da »kolege odgajatelje doživljavaju kao glavni oslonac i pomoć u radu«. I kod interveniranja uglavnom se »oslanjanju na kolege» (odgajateljski par ili kolege iz kuće) koji su im u tom smislu glavni izvor podrške.

lako sudionici verbaliziraju "pozitivan doživljaj stručne podrške«, izražavaju $i$ »nezadovoljstvo sadašnjim radom i angažmanom stručnih suradnika«. No, u kontekstu čimbenika koji olakšavaju nošenje s djecom u riziku, važan je kod »pozitivan doživljaj stručnih suradnika« koji se ogleda u partnerskom i timskom pristupu djetetu rizičnog ponašanja i kreiranju strategija intervencija, doživljaju korisnosti dobivenih smjernica ili preporučene stručne literature od pojedinih članova tima ovisno o teškoćama djeteta, važnosti drugog mišljenja i perspektive o ponašanju djetetu, iskazivanju vjere stručnih suradnika u odgajatelje da se mogu nositi s rizičnim ponašanjima (što im predstavlja dodatnu motivacija za rad) i sl.

O »učinkovitim intervencijama«, odnosno strategijama i načinima nošenja s rizičnim ponašanjima« odgajatelji izvještavaju navodeći brojne konkretne primjere i vlastita iskustva u radu. Na općenitoj razini, vidjeli smo, govore o pozitivnom stavu i pristupu prema djeci u riziku, odnosno afinitetu za rad s takvom djecom, važnosti odnosa s djetetom i usklađenosti intervencija s potrebama djeteta, te individualnom i individualiziranom, kao i grupnom pristupu (iako najčešće u negativnom kontekstu, odnosno kao neprimjerenom i neadekvatnom za djecu rizičnog ponašanja), važnosti timskog planiranja i programiranja intervencija za djecu rizičnog ponašanja. Međutim, osim navedenih općih pristupa i načela interveniranja, nabrajaju i specifične vrste intervencija ili strategija nošenja s rizičnim ponašanjima djece koje je moguće podijeliti u nekoliko većih skupina ovisno o tome kome su namijenjene: djeci u riziku, vršnjacima u grupi, roditeljima ili samom sebi, odnosno odgajatelju. Tako kada je riječ o djeci s rizičnim ponašanjima, uglavnom govore o »usmjerenosti odgajatelja na eksternalizirana ponašanja«, odnosno o nošenju s eksternaliziranim ponašanjima, što ne čudi s obzirom da su, kako i sami kažu, u radu najčešće usmjereni upravo na ta ponašanja jer su najvidljivija i najproblematičnija za rad skupine (zbog npr. organizacijskih problema, ali i njihove opasnosti za vršnjake u skupini, remećenje dinamike i rada odgojne skupine). Nastavno na njihovo »dominantno 
bavljenje eksternaliziranim problemima«, opisane intervencije odgajatelja moguće je podijeliti na »intervencije prema ili s djecom « $i$ »samokontrolu odgajatelja« (npr. zadržati kontrolu nad sobom i situacijom). Sve od strane sudionika navedene intervencije prema (s) djeci (om) rizičnih ponašanja moguće je sažeti na tzv. »klasične metode«: »poticanja, sprečavanja, prisiljavanja, navikavanja, uvjeravanja, odnosno strukturirajuće i aktivirajuće pedagoške postupke« uz, »rijetko spominjanje kreativnih/ alternativnih metoda i tehnika« (poput »rada s glinom kod agresivnog ponašanja ili korištenje audio-vizualnih metoda »snimanje djece u odgojnoj skupini«, »stol za jednu osobu«). Osim toga, »intervencije prema djeci i vršnjacima u odgojnoj skupini moguće je podijeliti i kao »intervencije usmjerene na razvoj socijalnih kompetencija« (npr. "jasna pravila ponašanja u grupi«, »vršnjaci kao modeli ponašanja«, "potkrjepljivanje pozitivnih ponašanja«, »socijalna integracija«, »izgradnja pozitivnih odnosa«, »rad s vršnjacima na prihvaćanju djeteta u riziku«, »strategije uključivanja i poticanja interakcije s vršnjacima...«), »razvoj emocionalnih kompetencija i regulaciju ponašanja« (»aktivnosti opuštanja«, »relaksacije i nošenja s neugodnim emocijama«, »empatiziranje s djetetom«, »kutić za emocije«, »mirni kutić", »nenasilna podrška dodirom«, »učenje prosocijalnih reakcija na ljutnju ili tugu«, »smirivanje djeteta pa individualne aktivnosti koje voli«, »smirivanje ponašanja«, "zaustavljanje agresivnog ponašanja«), »razvoj komunikacijskih vještina« (»kreiranje grupnih pravila u dogovoru s djecom«, »Ja poruke«, "jasna struktura«, "pravila i granice u skupini«). Potom ih je moguće objediniti i kao intervencije vezane uz »smanjenje poticaja za eksternalizirana ponašanja (»mir, a ne stalnipoticaji«, »ignoriranje nepoželjnih ponašanja«), te »metode sprečavanja« (»izdvajanje iz skupine i razgovor nakon okončanja agresivnog ponašanja«, »micanje opasnih predmeta iz dometa djece«, "povremeno izdvajanje djeteta iz skupine«, "premještanje djeteta u novu odgojnu skupinu«).

Nadalje, u kontekstu učinkovitih intervencija, odgajatelji su izvještavali i o »intervencijama s roditeljima« te u tom pogledu izražavaju svoju »osviještenost $o$ važnosti osnaživanja roditelja za odgoj", ali i »uključivanja i participativnog rada s roditeljima«. Kada je riječ o specifičnim intervencijama, spominju »informiranje roditelja o rizičnim ponašanjima « djeteta (ali ne i konkretnu podršku i savjetovanje) te vlastite »primjere dobre prakse (poput roditeljskih sastanaka s oba roditelja i parom odgajatelja, korištenja video snimki djeteta za argumentiranje procjene i ponašanja te pojašnjavanja/argumentiranja odgajateljskih intervencija roditeljima). Osim rada s roditeljima djece rizičnih ponašanja, navode još jedan aspekt koji je također često, prema iskazima sudionika, težak, a to je »rad s roditeljima vršnjaka iz odgojne skupine na prihvaćanju djeteta u riziku«.

$\mathrm{U}$ okviru ove kategorije, sudionici su navodili i »primjere učinkovitih programa prevencije problema u ponašanju« koje su primjenjivali u dosadašnjem radu poput »Paths«, »Rastimo zajedno« i »Nepoželjna ponašanja djece«, a koji se uglavnom,

\section{2 članci}


kako odgajatelji sami navode, unatoč pozitivnim evaluacijama i/ili iskustvima odgajatelja, više ne primjenjuju.

Spremnost odgajatelja na cjeloživotno obrazovanje također spada u ovu temu pa je moguće konstatirati da dio sudionika izražava »svjesnost o nužnosti rada na sebi i cjeloživotnog obrazovanja« i to kroz prepoznavanje važnosti imanja »ispušnog ventila u slobodno vrijeme za kvalitetan rad", "pohađanje edukacija i rada na sebi«, ali spominju i »samoedukaciju kroz stručnu literaturu«, pojašnjavajući kako je važno pratiti trendove i novine u ovom području, kako u literaturi, tj. znanstvenim i stručnim spoznajama, tako i u odnosu na sveopće društvene promjene i nove generacije djece (o čemu svjedoči kod: »biti u korak s vremenom«).

\section{2. tema „Čimbenici koji doprinose neučinkovitom nošenju odga- jatelja s rizičnim ponašanjima djece»}

Sažeto, ova tema kreće od središnje kategorije nazvane osjećaj nekompetentnosti odgajatelja za rad s djecom rizičnih ponašanja, ali i s njihovim roditeljima (od nedovoljne suradnje s roditeljima i neučinkovitim intervencijama u odnosu na dijete i roditelje) čemu snažno doprinosi i neadekvatna suradnja s timom i lokalnom zajednicom, nerazumijevanje i nedovoljna podrška tima u vrtiću, ograničen broj stručnog osoblja pa i osjećaj prevelike odgovornosti koja je na samim odgajateljima i njihovoj ulozi. Zbog navedenog odgajatelji imaju dojam da su intervencije prema djeci u riziku zakašnjele zbog čega rizična ponašanja često progrediraju i nastavljaju se kroz cijelo predškolsko pa i školsko razdoblje odrastanja djeteta. Osim zakašnjelih intervencija na razini vrtića, sudionici svjedoče i o nekorištenju intervencija zajednice, van vrtićkog okruženja. Drugim riječima, važan čimbenik kvalitetne inkluzije djeteta rizičnog ponašanja u odgojnu skupinu, koji se ogleda u dostupnosti stručne podrške (u vrtiću, ali i van vrtića), ne postoji, iako i sami odgajatelji uočavaju da bi u nekim slučajevima, posebice roditelje, ali i dijete, trebalo uključiti u druge intervencije van okruženja predškolske ustanove.

Upravo opisani čimbenici doprinose i stvaranju negativne slike djeteta s rizičnim ponašanjima od strane roditelja druge djece u skupini, vršnjaka u odgojnoj skupini pa i samih odgajatelja. Naime, zbog neučinkovitih reakcija odgajatelja na ponašanja djeteta (posebno eksternaliziranih rizičnih ponašanja), djeca u riziku ugrožavaju ostalu djecu u skupini, njihove potrebe, koheziju i funkcioniranje skupine, zbog čega nerijetko postaju etiketirana i neprihvaćena kako od vršnjaka u skupini tako i od njihovih roditelja. Pri tom se katkad i sami odgajatelji boje djece s intenzivnim eksternaliziranim ponašanjima jer se ne znaju adekvatno suočavati s njima.

Brojni organizacijski i strukturalni problemi koje navode, a koji otežavaju rad odgajatelja, zajedno s doživljajem negativnog statusa i ugleda odgajateljske struke 
općenito, svakako doprinose težini situacije i ukupnom neadekvatnom nošenju s rizičnim ponašanjima.

Zbog svih ovih činitelja, ne čudi da sudionici izvještavaju o teškim emocijama, odnosno osjećaju stresa, frustracije, bespomoćnosti, rezigniranosti, odustajanja i usamljenosti ili prepuštenosti samima sebi u nošenju s djecom u riziku i njihovim zahtjevnim ponašanjima na svakodnevnoj razini.

Tekst koji slijedi donosi detaljan prikaz ove teme kroz konkretne kategorije i kodove dobivene analizom.

Ova se tema, dakle, odnosi na faktore koji otežavaju rad s djecom rizičnih ponašanja, odnosno umanjuju mogućnost kvalitetnog rada i integraciju te djece u redovne predškolske ustanove. Analizom podataka izdvojeni su čimbenici opisani kroz slijedeće kategorije: »osjećaj nekompetentnosti za rad s djecom rizičnih ponašanja i njihovim roditeljima«, »nerazumijevanje i nedostatna podrška stručnog tima«, "zakašnjele intervencije«, »nekorištenje podrške i intervencija lokalne zajednice», »negativna slika djeteta s rizičnim ponašanjima od strane vršnjaka i njihovih roditelja pa i odgajatelja«, »loš društveni status odgajateljske profesije«, »organizacijski i strukturalni problemi« i »teške emocije odgajatelja«.

Ključni čimbenik neučinkovitog nošenja s rizičnim ponašanjima djece je kategorija »osjećaj nekompetentnosti odgajatelja«, a odnosi se na dvije veće potkategorije, odnosno na »nekompetentnost odgajatelja za rad s djecom rizičnih ponašanja« te za »rad s roditeljima«.

Naime, zbog »needuciranosti u dosadašnjem obrazovanju za rad s djecom rizičnog ponašanja« i općenito s »roditeljima«, »raskoraka teorije (kompetencija stečenih na fakultetu) i potreba prakse«, ali i pojedinih osobnih »iskustava neadekvatnog nošenja i reakcija prema djeci u riziku« (npr. gubitak samokontrole odgajatelja, preplavljenost emocijama, vikanje na dijete) tijekom karijere, gotovo svi su se odgajatelji (posebno oni s dužim radnim stažem) barem nekad osjećali »nekompetentno za rad s rizičnim ponašanjima«, odnosno »sumnjali su u vlastite kompetencije«. Pri tome, osim opisa »neadekvatnih vlastitih intervencija«što posljedično dovodi i do »osjećaja uzaludnog ulaganja truda i energije« (a bez rezultata), sudionici izvještavaju i o tome da se zbog toga katkada okreću i intuiciji, odnosno »intuitivnim reakcijama i intervencijama«.

Nadalje, i »za rad s roditeljima«, odgajatelji se uglavnom osjećaju »nekompetentno« ili za to nemaju vremena uslijed svih poslova i zadataka koje moraju obaviti. Tako i sami sudionici navode kako su »u radu usmjereniji na dijete nego na roditelje«. Naime, »rad s roditeljima za odgajatelje je težak", a ono što je posebno izazovno su brojni »problemi s kojima se odgajatelji suočavaju u radu s roditeljima« (od »otpora roditelja« koji se manifestira kroz opći otpor prema pomoći i nespremnost roditelja na suradnju, negiranje problema, opravdavanje ponašanja djeteta, usmjerenost na »instant« rješenja, do »neučinkovitih i neprimjerenih odgojnih postupaka i metoda

\section{4 članci}


roditelja«, ali i »negativnog doživljaja odgajatelja od strane roditelja« (u smislu da je odgajatelj »čuvar« djece ili dadilja koji se ne treba miješati u odgoj roditelja ili pak da naprosto stručne suradnike doživljavaju ozbiljnije od njih). Generalno gledajući, neki sudionici smatraju da je komunikacija u trijadi roditelj-odgajatelj-stručnjak nedovoljno transparenta i otvorena.

Čimbenik nazvan »nerazumijevanje i nedostatna podrška stručnog tima« sastoji se od dvije potkategorije, a definitivno otežava rad i osjećaj sigurnosti i sposobnosti da se odgajatelji suočavaju s rizičnim ponašanjima djece u odgojnim skupinama. Prva subkategorija »nezadovoljstvo radom i angažmanom stručnog tima« sažeto govoreći prenosi poruku da je podrška koju stručni suradnici trenutno pružaju odgajateljima nedostatna (odnosno da trebaju intenzivniju podršku stručnog tima). Nedostatak podrške sigurno utječe i na spomenuti »osjećaj nemoći« za rad s rizičnim ponašanjima generalno opisan kasnije u okviru ove teme.

Kod »nedostatna podrška tima«, odnosi se, prema izjavama odgajatelja, i na individualni, a ne potrebni grupni rad/pristup djetetu u riziku (što je odgajateljima irelevantno jer su stalno u grupnim uvjetima) te rijetke dolaske članova tima u skupinu s djetetom koje manifestira rizična ponašanja kao i nepostojanje rasporeda obilaska vrtića od strane stručnih suradnika. Nadalje, neki odgajatelji imaju negativan doživljaj struke psihologa (»samo dijagnosticiraju, ne interveniraju i ne pomažu«). Smeta im i »čest doživljaj rizičnih ponašanja kao prolazne razvojne faze od strane stručnih suradnika«. Vezano uz ovu temu, navode iskustva s »jednokratnim procjenama« pojedine djece od strane stručnog tima kao loš primjer jer to na koncu niti »nije stručna procjena«.

Paralelno s ovim negativnim doživljajem stručnih suradnika od strane dijela odgajatelja, evidentan je i doživljaj »negativnog doživljaja odgajatelja od strane članova stručnog tima«. U ovu subkategoriju izolirani su kodovi: »ignoriraju upite odgajatelja«, »ne uvažavaju mišljenje odgajatelja« (oko sumnje na rizično ponašanje, mišljenja oko upisa u školu i sl.), »ne shvaćaju odgajatelje ozbiljno", »odgajatelji ne znaju svoj posao", »odgajatelji nekompetentni za rad s rizičnom djecom «, »želja da se potreba za podrškom shvaća ozbiljno od stručnog tima«, »nemogućnost pisanja realnog, relevantnog i argumentiranog mišljenja o spremnosti djeteta za upis u školu«. Posljednji kod odnosi se na interpretaciju odgajatelja da svoja mišljenja i prijedloge moraju pisati »upakirano«, neistinito, isključivo pozitivno čime, kako i sami kažu, zapravo najviše "gubi« škola (ali i dijete!, op.a.) jer ne dobiva relevantne i realne podatke o djetetu prilikom upisa.

Nastavno na upravo opisanu nedovoljnu suradnju i negativne međusobne percepcije odgajatelja i članova stručnog tima, naslanja se i kategorija naziva »zakašnjele intervencije«. Odgajatelji se uglavnom slažu u mišljenju da se »sadašnja procjena $i$ interveniranje događa prekasno « te govore o »potrebi pravovremene procjene i rane intervencije« budući da je to važno za rješavanje problema koje dijete 
pokazuje. U tom smislu i predlažu uvođenje »procjene djece već u vrlo ranoj dobi« (pa i jasličkoj). O zakašnjelim i nepravovremenim intervencijama prema djetetu u riziku svjedoči i kod nazvan »kontinuitet i progrediranje rizičnih ponašanja zbog neučinkovitih intervencija«.

Kategorija »nekorištenje podrške i intervencija lokalne zajednice« još je jedan čimbenik koji otežava rad i nošenje odgajatelja s nepoželjnim ponašanjima djece u odgojnoj skupini. Sudionici pod tim vidom, izražavaju, s jedne strane, vlastitu "nespremnost da prijave roditelje zbog neadekvatnog odgoja nadležnim institucijama", dok s druge jasno navode kako su pojedinim obiteljima "potrebne dodatne intervencije" (daleko strukturiranije i intenzivnije od onih koje predškolska ustanova može ponuditi) dostupne u lokalnoj zajednici poput, primjerice, »obiteljske psihoterapije«. Međutim, dio sudionika izvještava i o »nepostojanju potrebnih usluga i servisa pomoći i podrške roditeljima u gradu Rijeci«, a kod nekih sugovornika je evidentno i »nepoznavanje dostupnih intervencija u lokalnoj zajednici« u kojoj žive i rade.

Sve navedene neadekvatne intervencije i teškoće u radu dovode do »negativne slike djeteta s rizičnim ponašanjima od strane vršnjaka i njihovih roditelja pa i odgajatelja«. Ta se kategorija sastoji od kodova »strah odgajatelja od djece rizičnih ponašanja« ("Samo da ne dođe u moju grupu!«), ali i straha druge djece vršnjaka u odgojnoj skupini što pojašnjava potkategorija »djeca rizičnih ponašanja ugrožavaju potrebe druge djece u skupini«, odnosno njeni kodovi: »rizična djeca izazivaju strah i stres kod djece", »narušavaju koheziju i funkcioniranje grupe", »ugrožavaju sigurnost djece u skupini« $i$ »zabrinutost odgajatelja za nezadovoljene potrebe druge djece zbog fokusa na rizičnu«. Zbog svega navedenog, ne čudi da "vršnjaci djecu u riziku ne prihvaćaju« te su »djeca rizičnih ponašanja etiketirana«. No, i »roditelji druge djece«, pa i »odgajatelji katkad teško prihvaćaju« djecu u riziku što doprinosi ukupnoj negativnoj slici djeteta, posebno s eksternaliziranim rizičnim ponašanjima.

Nadalje, »loš društveni status odgajateljske profesije« još je jedan nepovoljan činitelj koji podrazumijeva »negativan imidž njihove struke u javnosti«, »neuvažavanje odgajatelja«, ali i »vrtića kao institucije« (škola se doživljava puno važnijom) te »okrivljavanje odgajatelja za rizična ponašanja djeteta« (najčešće od strane roditelja, ali katkad i, vidjeli smo ranije, stručnih suradnika).

Vezano uz sve navedeno, sudionici prepoznaju i »organizacijske probleme« i uvjete rada koji onemogućuju ili otežavaju rad s djecom u riziku pa tako osim »općenito teških uvjeta rada odgajatelja« i otegotnih okolnosti za detekciju i intervencije prema djeci s rizičnim ponašanjima, političke situacije u zemlji i manjka financija u sustavu predškolskog odgoja, politiku zabrane zapošljavanja navode i »fluktuaciju odgajatelja« koja nepovoljno utječe na djecu s rizičnim ponašanjima, »/ošu organizaciju radnog vremena« (prekratko preklapanje smjena odgajatelja što onemogućuje kvalitetnu razmjenu informacija o djetetu), »manjak vremena za

\section{6 članci}


adekvatno bavljenje s djecom u riziku«, »neadekvatnost mješovitih grupa za kvalitetan rad« (interesi i potrebe djece u mješovitim skupinama različiti, prevelik dobni raspon djece, teškoće pronalaženja prikladnih aktivnosti, nemogućnost posvećivanja svoj djeci radi njihovih različitosti), »neadekvatnost grupnog pristupa za djecu s rizičnim ponašanjima«, »povećanje administrativnih poslova odgajatelja« te »smjenski rad vrtića kao rizik« budući da nije u skladu s potrebama djeteta (cjelodnevni rad vrtića, tjedna izmjena smjena zbog čega djeca gotovo uopće nisu s roditeljima i nemaju prijeko potrebnu strukturu dnevnih aktivnosti i rutina).

Na to se nadovezuju i tzv. »strukturalna pitanja«ili, bolje rečeno, problemi: već više puta spomenuti »nedovoljan broj dostupnih stručnih suradnika« (na broj djece) i »preopterećenost stručnih suradnika u vrtiću« (nedovoljna podrška odgajateljima, predug protok vremena od detekcije odgajatelja do podrške tima), »manjak edukacijsko-rehabilitacijskih stručnjaka u gradu«, "prevelik broj djece po odgojnoj skupini« (što otežava rad s djecom općenito, ali posebno s djecom koja manifestiraju internalizirane probleme) te »nepostojanje sustavnog praćenja djece rizičnih ponašanja u smislu evaluacije« poduzetih intervencija.

Svi do sada pojašnjeni rizični čimbenici za uspješno nošenje s rizičnim ponašanjima djece negativno utječu na odgajatelje pa tako sudionici izvještavaju i o vlastitim »teškim emocijama«. U okviru ove kategorije svjedoče o doživljaju »stresa i frustriranosti poslom odgajatelja«. Pod tim vidom govore o tome da odgajatelji "posao nose kući (često razmišljaju o djeci u riziku i u slobodno vrijeme) te da »na posao dolaze s grčem« ili da su "završili na bolovanju radi rada s djetetom rizičnog ponašanja«. Osim toga, osjećaju i »veliku odgovornost, ali i vlastitu izloženost« kako drugim kolegama tako i roditeljima (često ih pitaju - »Što ste napravili za rješavanje problema?«). Zbog svega navedenog, vlastiti posao i rad s djecom u riziku procjenjuju »teškim«. Nadalje, neki sudionici govore i o »osjećaju nemoći i bespomoćnosti za rad i nošenje s ponašanjima djece u riziku« čemu sigurno doprinose opisani »osjećaj nekompetentnosti za rad s djecom rizičnih ponašanja«, ali i »nedostatak podrške» (»nemaju se na koga osloniti«). S obzirom na to, ne čudi što dio odgajatelja svoj "posao opisuje usamljeničkim« ili »postaje rezignirano (odustaju od rada s roditeljima, odustaju zbog nesuradljivih roditelja, posao odgajatelja troši osobu, razumijevanje mlađih kolega za rezigniranost starijih odgajatelja u radu, trud i energija bez rezultata povećavaju osjećaj rezigniranosti, mlađi odgajatelji entuzijastičniji u radu i sl.).

\section{3. tema: „Preporuke za unaprjeđenje rada s djecom rizičnih ponašanja»}

U ovoj su temi sažete sve preporuke sudionika istraživanja koje se odnose na unaprjeđenje sustava i procedura pri čemu navode niz ideja koje su odraz njihovog iskustva, ali i teškoća i izazova s kojima se u radu susreću. 
Tema se sastoji od sedam kategorija i pripadajućih im kodova, a s to su: »vjera u promjenu«, »češća i dostupnija stručna pomoć«, »dodatne edukacije i rad na sebi«, "promjene u edukaciji budućih odgajatelja«, "potreba za umrežavanjem sustava i intervencija van vrtića《, »uvođenje programa ranih intervencija i prevencije problema u ponašanju« $\mathrm{i}$ »organizacijske preporuke«.

Prije svega, važno je konstatirati da značajan broj odgajatelja »vjeruje u promjene«, odnosno da je promjena na bolje moguća te da u tom pogledu treba ići bottom-up pristupom »oslanjajući se na postojeće kapacitete « predškolskih ustanova u smislu stručnih djelatnika i uvođenje organizacijskih preinaka (radnog vremena, uvođenje volontera kao pomagača u skupinama, reorganizacije rada stručnog tima i sl.). Pri tom napominju da je »promjena moguća, ali spora«, »ne ide preko noći« i iziskuje angažman i doprinos (pa makar i mali) svih koji rade u vrtiću.

Već više puta spominjana je i kategorija »češća i dostupnija stručna pomoć« koju čine, između ostalog, i kodovi "povećati broj stručnog kadra« (npr. stručni tim po vrtiću) te "potreba za pomagačima-asistentima u skupinama s ciljem kvalitetnijeg rada«. Ona se odnosi na prijedlog uvođenje volontera, asistenata, ali pomažućih profesija s tim da predlažu da volontiranje bude kontinuirano. Neki od prijedloga bili su i da volonteri budu nezaposleni psiholozi i pedagozi. Osim toga, sudionici istraživanja navode i da su sami odgajatelji spremni educirati volontere.

»Potreba za procjenom i intervencijom u grupnim uvjetima« vezana je uz to da je, kako je već rečeno, individualna procjena i podrška odgajateljima irelevantna jer rade u grupnim uvjetima pa otuda i potreba za pomoći odgajateljima u grupnim uvjetima rada, a ne individualnim.

»Osnivanje povjerenstva za rizična ponašanja iz reda odgajatelja« prijedlog je izrastao iz očigledno dobrog iskustva s postojećim Povjerenstvom za prevenciju zlostavljanja i zanemarivanja u vrtiću koje ima ulogu podrške i pomoći odgajateljima kada se nađu u problemu. Nadalje, kod »osnivanje savjetovališta za odgajatelje" jasan je sam po sebi, a podrazumijeva telefonsko savjetovanje ili uživo sa stručnim suradnicima, konzultacije i zajedničko planiranje i programiranje odgajatelja i stručnjaka. Riječ je, dakle, o savjetovalištu kao obliku pomoći odgajateljima u radu $s$ djecom i roditeljima u riziku.

»Dodatne edukacije i rad na sebi« odnose se na »edukacije odgajatelja za rad s djecom u riziku« (tematske radionice, primjeri dobre prakse, grupe podrške i rad s roditeljima, preporuka stručne literature za nošenje sa specifičnim teškoćama djeteta), otvaranje »stručne knjižnice za odgajatelje« na razini vrtića te »studijske posjete radi izmjene iskustava«, ali $\mathrm{i}$ »uvođenje supervizije odgajatelja« .

Osim toga, odgajatelji predlažu i »promjene u edukaciji budućih odgajatelja«, odnosno drugačije obrazovanje za profesionalnu ulogu odgajatelja pa tako odnosno šalju poruku fakultetima da »bolje pripreme studente za obavljanje prakse $u$

\section{8 članci}


vrtićima«, »uvedu kolegije rada s roditeljima« $i$ »intervencija prema djeci s problemima u ponašanju« u obrazovanje odgajatelja.

Odgajatelji uočavaju i »potrebu za umrežavanjem sustava i intervencijama van vrtića« što počiva na »manjku institucija i dostupnih usluga za djecu s problemima u ponašanju u Rijeci«, »nepovezanost postojećih institucija«, ali i evidentnom »nepoznavanju dostupnih usluga u gradu« od strane pojedinih odgajatelja. U skladu s tim, govore o važnosti »suradnje na međuinstitucionalnoj i interdisciplinarnoj razini« (kontakti odgajatelja sa školom kod upisa, prošireni interdisciplinarni stručni timovi sa školom, suradnja s Centrom za socijalnu skrb Rijeka, Dječjom bolnicom Kantrida i sl.).

Nadalje, predlažu i »sustavni i interdisciplinarni pristup djeci u riziku«. Naime, kreću od činjenice da trenutni pristup djeci s rizičnim ponašanjima nije interdisciplinarno niti sustavno organiziran, pa predlažu redovitu, kontinuiranu i transparentnu komunikaciju, dokumentiranje podataka, kvalitetnu razmjenu informacija, informatizaciju sustava, standardizaciju postupaka detekcije, procjene i praćenja djeteta, sistematiziranu i potpunu dokumentaciju o djeci u riziku te »uvođenje pravog timskog rada«, ponajprije u vrtiću pa i šire, posebno u smislu planiranja i programiranja intervencija i transparentnu komunikaciju odgajatelja, stručnih suradnika i sl.

»Uvođenje strukturiranih i učinkovitih programa ranih intervencija i prevencije problema u ponašanju« također je jedna od preporuka, kao i »programa i intervencija za osnaživanje roditeljskih kompetencija« na razini vrtića, ali i šire (npr. radionice, škola za roditelje, savjetovalište za roditelje i sl.).

Kao »organizacijske preporuke« navode potrebu da se »djeca s rizičnim ponašanjima smjeste u manje skupine s dodatno educiranim odgajateljima za tu tematiku«, da se »smanji broj djece u skupinama te da se, već spomenuto, »uvede duže preklapanje smjena odgajatelja radi kvalitetnije razmjene informacija o djeci«.

\section{RASPRAVA I ZAKLJUČAK}

$\mathrm{Na}$ istraživačka pitanja: »Kako se odgajatelji suočavaju s rizičnim ponašanjima djece u svom radu? $\mathrm{i}$ »Kako doživljavaju vlastitu kompetentnost za rad s djecom koja manifestiraju rizična ponašanja u vrtićkom okruženju?» odgovaraju dvije teme: „Čimbenici koji doprinose adekvatnom nošenju s rizičnim ponašanjima djece« $i$ „Čimbenici koji doprinose nošenju odgajatelja s rizičnim ponašanjima djece. Riječ je o, mogli bismo reći, ambivalentnom doživljaju odgajatelja za nošenje s rizičnim ponašanjima djece $s$ kojom rade kao i ambivalentnom doživljaju vlastite kompetentnosti za to, odnosno o svojevrsnoj osi s dva pola (od neadekvatnog suočavanja i osjećaja nekompetentnosti do učinkovitog nošenja i osjećaja kompetentnosti, ali samo za određene segmente stručnog rada s djecom rizičnih ponašanja). 
Kada govorimo o kompetencijama odgajatelja za rad s djecom u riziku, evidentno je da su odgajatelji svjesni važnosti svoje uloge u nošenju s rizičnim ponašanjima koja proizlazi iz njihovog kontinuiranog svakodnevnog neposrednog kontakta s djecom, ali i obveza ili očekivanja koje im nalaže i sama struka i profesionalizam (pa su dužni reagirati), što potvrđuje prethodne nalaze Vlah i Ferić (2017.). Odgajatelj je stoga, prema viđenju sudionika istraživanja, barem u kontekstu vrtića, ključna figura u radu s djecom s rizičnim ponašanjima, a važnost razvijenosti/posjedovanja njihovih kompetencija za poduzimanje adekvatnih intervencija prema djetetu rizičnog ponašanja, vršnjacima u skupini i roditeljima proizlazi iz upravo navedenog.

Kao svojevrsni preduvjeti kompetentnog rada izolirani su zainteresiranost za rad s djecom rizičnog ponašanja, pozitivan stav prema poslu i djeci (općenito, ali i s rizičnim ponašanjima i razumijevanje za roditelje djece u riziku). Kada govore o vlastitoj kompetentnosti, pozivaju se na senzibiliziranost za rano prepoznavanje rizičnih ponašanja pa u tom smislu ponajviše posjeduju i primjenjuju znanja i vještine vezane uz detekciju rizičnih ponašanja, koriste neke intervencije koje procjenjuju učinkovitima (posebno u odnosu na samo dijete rizičnog ponašanja i vršnjake u odgojnoj skupini s ciljem prihvaćanja djeteta u riziku, dok u odnosu na intervencije s roditeljima nisu kompetentni, osim u pogledu informiranja roditelja o rizičnim ponašanjima djeteta). Odgajatelji pozitivno ocjenjuju i važnost intervencija usmjerenih na vlastitu samokontrolu ponašanja, a posebno teških emocija koje ta djeca katkada, zbog intenziteta i težine ponašanja koja manifestiraju, izazivaju kod odgajatelja. Nadalje, u kontekstu strategija nošenja govore, na općenitoj razini, o spomenutom pozitivnom pristupu djetetu, razvoju kvalitetnog odnosa s djetetom, usklađenosti intervencija i potreba, individualnom i individualiziranom pristupu kao učinkovitom, suradnji s timom i kolegom iz para odgajatelja (u kontekstu planiranja i programiranja intervencija), a od konkretnih intervencija sažeto možemo izdvojiti tzv. klasične intervencije usmjerene prema djeci (i vrlo rijetko prisutne kreativne i alternativne metode i tehnike). Posebno se izdvaja primjer učinkovitog prevencijskog programa »Paths - Rastimo zajedno« (a o njegovoj učinkovitosti govore i Novak i sur., 2016.) koji se više ne provodi.

Iz analize podataka saznali smo i da odgajatelji imaju primjeren vrijednosni sustav za rad s djecom (od poznavanja suvremenih pristupa i principa rada s djecom rizičnih ponašanja do višestrukog isticanja potrebe za pravim timskim pristupom i radom kojeg su, mogli bismo reći, željni (što ne čudi s obzirom na ograničene kompetencije odgajatelja u kontekstu poznavanja i korištenja adekvatnih intervencija, ali i zbog drugih izazova u radu s kojima se svakodnevno susreću). Komunikacija i suradnja svih uključenih u djetetov život pokazali su se ključnim elementima kompetentnog nošenja odgajatelja s djecom u riziku u ovom istraživanju.

\section{0 članci}


Važno je spomenuti da sudionici ukazuju i na potrebu, ali i vlastitu spremnost za rad na sebi kao i za cjeloživotno obrazovanje na temu djece i mladih u riziku.

Drugi smjer odgovora ide u prilog osjećaju nekompetentnosti za nošenje s rizičnim ponašanjima djece opisan uglavnom kroz temu: »Čimbenici koji doprinose neučinkovitom nošenju odgajatelja s rizičnim ponašanjima djece«. To znači da govore o stresnosti rada s eksternaliziranim rizičnim ponašanjima (slično kao i Abidin i Robinson, 2002., prema Picarald, 2012.) i težini posla iz čega proizlazi da se osjećaju nemoćno, frustrirano (pa i sumnjaju u vlastite kompetencije), a katkada i posve nekompetentno (što zbog needuciranosti za rad s djecom u riziku, ali i zbog osobnih loših iskustava u radu s takvom djecom) pa i rezignirano. Vlastiti posao neki dio sudionika ovog istraživanja doživljava i usamljeničkim (ponajprije zbog neadekvatne podrške i suradnje s timom). Posljedično, neki iznose i neadekvatne reakcije odgajatelja na dijete (poput gubitka samokontrole, preplavljenosti emocijama i sl.). Hart Bell i Quinn (2004., prema Picarald, 2012.) u svom radu govore o osjećaju frustracije i očaja odgajatelja, a Picarald (2012.) navodi kako manjak kompetencija ograničava adekvatne odgovore na problematična i izazovna ponašanja djece.

Budući da o kompetencijama odgajatelja postoje brojni dokumenti i radovi te su one dobro poznate, stoga se ovdje neće posebno eleaborirati (primjerice $u$ Bašić, 2008.; Kardum, Dujmović i Kardum-Bošnjak, 2008.; Bouillet, 2010.; Ivaštanin i Vrbanec, 2015.; Kuhar i Sindik, 2011.; Sindik i Karalić, 2012.; Vlah i Ferić, 2017.; Jurčević-Lozančić, 2018.).

Osim navedenog, teškoće u radu odgajatelja moguće je prepoznati i kroz nezadovoljstvo radom i angažmanom stručnog tima i negativan doživljaj odgajatelja od strane članova stručnog tima koji se prvenstveno odnose na lošu suradnju i nedostatnu podršku odgajateljima, ali i na nekvalitetnu suradnju s roditeljima, što potvrđuje rezultate iz kvantitativnog dijela istraživanja ovog projekta u Dječjem vrtiću Rijeka (Vlah i Ferić, 2017.). Bouillet (2010.), kao i Bašić (2008.), zaključuju kako je uloga vrtića uspostavljanje kvalitetne suradnje s roditeljima i jačanje roditeljskih kompetencija te pod tim vidom naglašavaju kako je, uz tradicionalne oblike komunikacije (roditeljski sastanci, radionice, priredbe...), potrebno kreirati nove načine uspostavljanja odnosa s roditeljima.

Nadalje, analizom podataka izdvojeni su i sljedeći izazovi: nužnost uvođenja rane detekcije, procjene i intervencije (sadašnje intervencije događaju se prekasno), loš društveni status odgajateljske profesije, organizacijski i strukturalni problemi (manjak financija, fluktuacija odgajatelja, loše radno vrijeme, prevelike odgojne skupine, neadekvatnost grupnih uvjeta rada za djecu u riziku, previše administracije, premali broj članova tima....) te potreba za uključivanjem roditelja u sustave/ 
intervencije izvan sustava ranog i predškolskog odgoja i obrazovanja. Slično navodi i Bouillet (2010.) upozoravajući kako se sve navedeno negativno odražava na kvalitetu predškolskog odgoja.

lako i same opisane teškoće u radu zasigurno mogu biti i dio preporuka, odgajatelji su eksplicitno navodili sljedeće preporuke: češća i dostupnija stručna pomoć, uvođenje promjena u inicijalno obrazovanje odgajatelja na fakultetu, umrežavanje i transdisciplinarni pristup, dodatne edukacije i supervizije odgajatelja, implementacija na dokazima utemeljenih programa prevencije i rane intervencije, ali i niz organizacijskih preporuka. O cjeloživotnom obrazovanju (u vidu treninga, konzultacija, mentoriranja, supervizije, timske refleksije, suradničkog rješavanja problema) govore i Hirschland (2011., prema Picarald, 2012.) i Whittaker i Harden (2010.), a potonji autori spominju i važnost ekstenzivne podrške odgajateljima u radu od strane stručnog tima.

Razumijevanje doživljaja i iskustava odgajatelja koji svakodnevno rade s djecom koja manifestiraju rizična ponašanja donosi uvide koji bi trebali pomoći i djeci s problemom i onima koji pripremaju buduće odgajatelje za rad, ali i stručnjacima koji pomažu odgajateljima u radu pa i političarima odnosno donositeljima odluka.

Zaključci ovog istraživanja potvrđuju rezultate stranih i malobrojnih hrvatskih (Sindik, 2012.; Tatalović Vorkapić, 2015.; Vlah, Smojver-Ažić i Dorčić Martinac, 2017.; Vlah i Ferić, 2017.; Jurčević-Lozančić, 2018.) te idu u prilog tome da postoji potreba (ili nužnost!) za dodatnim osposobljavanjem djelatnika dječjih vrtića kako bi se osjećali kompetentnijima i kako bi osigurali potrebne uvjete za odgoj i obrazovanje svakom djetetu. Usto, iz rezultata proizlazi i potreba za uvođenjem većeg broja stručnjaka, posebice, prema mišljenju autorica, socijalnih pedagoga (koji se u službenim dokumentima i zakonskom okviru profila stručnih radnika u vrtiću NE spominju), a koji su educirani za kreiranje i implementaciju programa za prevenciju rizičnih ponašanja i promociju mentalnog zdravlja djece u predškolskim ustanovama, odnosno završetkom studija stječu kompetencije za rad i s djecom koja iskazuju probleme u ponašanju ili su u riziku za njihov razvoj.

Kako bismo u vrtićima imali kompetentne odgajatelje, odnosno, kako je još davne 1997. godine navela Žižak (1997::8) »one koji doživljavaju svoja znanja, vještine i osobne karakteristike integrirane tako da im pružaju osjećaj moći, sposobnosti i znanja kako raditi s djecom«, sigurno se još moramo pozabaviti kvalitetom edukacije odgajatelja za ovo područje, dostupnošću stručne podrške, ali i većem uključivanju socijalnih pedagoga u vrtiće, kao i kvalitetom koordinacije i integracije podržavajućih servisa i usluga, no i brojnim drugim, iz perspektive odgajatelja, navedenim faktorima, a sve s ciljem kako odgajatelj ne bi bio samo još jedan rizični (umjesto zaštitnog) čimbenik za dijete i njegov razvoj.

\section{2 Članci}


Kako je i uvodno spomenuto, ali i prema iskazu sudionika istraživanja, ako se ne reagira na vrijeme, ponašanje će progredirati te su stoga prevencija i rane intervencije u ranoj i predškolskoj dobi od izuzetnog značaja. Znanstveno dokazano učinkoviti programi i intervencije u ovom području poznati su kao i moguće preporuke i smjernice za rad koji zaista funkcionira i učinkovit je. Međutim, i ovo istraživanje pokazuje da je i dalje evidentan ogroman raskorak između znanja o prevenciji i intervencijama utemeljenim na dokazima i prakse, odnosno onoga što djeca s rizičnim ili teškoćama u ponašanju svakodnevno u vrtićima doživljavaju kao »intervenciju«. Stoga bi ovaj rad mogao predstavljati doprinos suvremenom shvaćanju odgojno-obrazovne prakse, kao nizu nepredvidivih, promjenjivih $\mathrm{i}$ međusobno povezanih interakcija između svih sudionika. Također može predstavljati doprinos afirmaciji i priznavanju promjenjive uloge odgajatelja koji aktivno doprinosi spoznajama o djeci s problemima u ponašanju i tako dopunjuje znanstvena istraživanja koja ne mogu u potpunosti obuhvatiti široku problematiku odgojne prakse.

Zaključno je u kratkim crtama moguće konstatirati da, kad je riječ o čimbenicima koji doprinose učinkovitom nošenju odgajatelja s rizičnim ponašanjima djece, uočljivo je da je većina izoliranih kategorija usmjerena na procjenu vlastite kompetentnosti odgajatelja, uloge, pozitivnih stavova i rada na sebi (te važnosti odgajatelja kao »dijela« timskog pristupa), dok je kod iskaza o neučinkovitom nošenju odgajatelja s rizičnim ponašanjima djece većina kategorija usmjerena na čimbenike izvan »dometa« odgajatelja što kod njih izaziva stres i doživljaj vlastite nekompetentnosti (nedovoljna suradnja sa stručnjacima iz tima, s roditeljima djece, neuvažavanje i loš status odgajatelja, izostanak pravovremenih intervencija, nepovezanost s intervencijama u zajednici itd.). To bi značilo da odgajatelji smatraju svoju ulogu i značaj ključnom, kao i kompetencije, ali se u tome osjećaju usamljeno, odnosno, prepušteni su sami sebi, a što sigurno ne može biti adekvatno ni učinkovito niti za djecu, niti za roditelje, a niti za same odgajatelje. To je važna spoznaja za ovo, kao i buduća istraživanja. 
Prilog 1. Prikaz tema i pripadajućih kategorija

\begin{tabular}{|c|c|}
\hline Teme & Kategorije \\
\hline $\begin{array}{l}\text { Čimbenici koji } \\
\text { doprinose } \\
\text { adekvatnom nošenju } \\
\text { odgajatelja s rizičnim } \\
\text { ponašanjima djece }\end{array}$ & $\begin{array}{l}\text { Svijest o važnosti vlastite uloge u nošenju s rizičnim } \\
\text { ponašanjima } \\
\text { Pozitivni stavovi prema radu s djecom i afinitet za rad s djecom } \\
\text { rizičnih ponašanja } \\
\text { Razumijevanje i uvažavanje roditelja } \\
\text { Kompetentnost za prepoznavanje rizičnih ponašanja } \\
\text { Svijest o važnosti suvremenih pristupa i načela u radu s } \\
\text { djecom rizičnih ponašanja } \\
\text { Svijest o važnosti timskog rada/suradnje za rješavanje } \\
\text { problema i spremnost odgajatelja na suradnju } \\
\text { Učinkovite intervencije } \\
\text { Svjesnost o nužnosti rada na sebi i cjeloživotnog obrazovanja } \\
\text { odgajatelja }\end{array}$ \\
\hline $\begin{array}{l}\text { Čimbenici koji } \\
\text { doprinose } \\
\text { neučinkovitom } \\
\text { nošenju odgajatelja s } \\
\text { rizičnim ponašanjima } \\
\text { djece }\end{array}$ & $\begin{array}{l}\text { Osjećaj nekompetentnosti za rad s djecom rizičnih ponašanja i } \\
\text { njihovim roditeljima } \\
\text { Nerazumijevanje i nedostatna podrška stručnog tima } \\
\text { Zakašnjele intervencije } \\
\text { Nekorištenje podrške i intervencija lokalne zajednice } \\
\text { Negativna slika djeteta s rizičnim ponašanjima od strane } \\
\text { vršnjaka i njihovih roditelja pa i odgajatelja } \\
\text { Loš društveni status odgajateljske profesije } \\
\text { Organizacijski i strukturalni problem } \\
\text { Teške emocije odgajatelja }\end{array}$ \\
\hline $\begin{array}{l}\text { Preporuke za } \\
\text { unaprjeđenje rada } \\
\text { s djecom rizičnih } \\
\text { ponašanja }\end{array}$ & $\begin{array}{l}\text { Vjera u promjenu } \\
\text { Češća i dostupnija stručna pomoć } \\
\text { Dodatne edukacije i rad na sebi } \\
\text { Promjene u edukaciji budućih odgajatelja } \\
\text { Potreba za umrežavanjem sustava i intervencija van vrtića } \\
\text { Uvođenje programa ranih intervencija i prevencije problema u } \\
\text { ponašanju } \\
\text { Organizacijske preporuke }\end{array}$ \\
\hline
\end{tabular}

\section{4 članci}




\section{LITERATURA}

1. Bašić, J. (2008). Kompetentnost odgajatelja i prevencija rizičnih ponašanja djece u odgojnim ustanovama. Kriminologija \& socijalna integracija: Časopis za kriminologiju, penologiju i poremećaje u ponašanju, 16 (2), 15-27.

2. Bašić, J., Ferić Šlehan, M. \& Kranželić Tavra, V. (2007). Zajednice koje brinu - model prevencije poremećaja u ponašanju: Epidemiološka studija - mjerenje rizičnih i zaštitnih čimbenika u Istarskoj županiji. Pula, Zagreb: Istarska županija.

3. Benedict, E. A., Horner, R. H. \& Squires, J. K. (2007). Assessment and implementation of positive behavior support in preschools. Topics in Early Childhood Special Education, 27, 174-192. https://doi.org/10.1177/02711214070270030801

4. Bogović, A., Majdančić, A. \& Ivezić, E. (2016). Programi rane intervencije u svijetu, istraživanja i evidence-based pristup. U: Restek-Petrović, B., Filipčić, I. (ur.), Rana intervencija kod psihotičnih poremećaja. Zagreb: Medicinska naklada, 23-28.

5. Boričević Maršanić, V., Zečević, I., Paradžik, Lj., Šarić, D. \& Karapetrić-Bolfan, Lj. (2015). Kognitivne tehnike u kognitivno bihevioralnoj terapiji mlađe djece $s$ eksternaliziranim poremećajima. Socijalna psihijatrija, 43(4), 183-190.

6. Bouillet, D. (2010). Izazovi integriranog odgoja i obrazovanja. Zagreb: Školska knjiga.

7. Braun, V. \& Clarke, V. (2006). Using thematic analysis in psychology. Qualitative Research in Psychology, 3 (2), 77-101. https://doi.org/10.1191/1478088706qp063oa

8. Braun, V. \& Clarke, V. (2012). Thematic analysis. In Cooper, H., Camic, P. M., Long, D. L., Panter, A. T., Rindskopf, D. \& Sher, K. J. (eds.), APA handbook of research methods in psychology. Vol. 2. Research designs: Quantitative, qualitative, neuropsychological, and biological. Washington: American Psychological Association, 55-71. https://doi.org/10.1037/13620-004

9. Brown, C. M., Bignall, W. J. R. \& Ammerman, R. T. (2018). Preventive behavioral health programs in primary care: a systematic review. Pediatrics, 141 (5). https:// doi.org/10.1542/peds.2018-0611

10. Bruner, J. (2000). Kultura obrazovanja. Zagreb: Educa.

11. Clarke, V. \& Braun, V. (2013). Successful qualitative research: A practical guide for beginners. London: Sage.

12. Colman, I., Wadsworth M., Croudace T. \& Jones, P. (2007). Forty-year psychiatric outcomes following assessment for internalizing disorder in adolescence. American Journal of Psychiatry, 164 (1), 126-133. https://doi.org/10.1176/ ajp.2007.164.1.126

13. Creswell, J. (2013). Qualitative inquiry and research design: Choosing among five traditions (3rd edition). Thousand Oaks, CA: Sage. 
14. Curtis, P. R., Roberts, M. Y., Estabrook, R. \& Kaiser, A. P. (2017). The longitudinal effects of early language intervention on children's problem behaviors. Child Development, 00 (0), 1-17. https://doi.org/10.1111/cdev.12942

15. Picarald, M. D. (2012). Practitioners' perceptions about their management skills of challenging behaviour among kindergarten children (a Maltese sample). Master's thesis. Oslo, Dublin: Oslo and Akershus University College of Applied Sciences, Dublin Institute of Technology and University of Malta. Preuzeto s: http://www. hioa.no/eng/content/download/24998/319317/file/Daisy.pdf (1.10.2018.)

16. Dunlap, G., Strain, P. S., Fox, L., Carta, J. J., Conroy, M., Smith, B. J., Kern, L. et al. (2006). Prevention and intervention with young children's challenging behavior: Perspectives regarding current knowledge. Behavioral Disorders, 32 (1), 29. https://doi.org/10.1177/019874290603200103

17. Falk, I. \& Guenther, J. (2007). Generalising from qualitative research: Case studies from vet in contexts. Preuzeto s: https://avetra.org.au/documents/10-Guenther. pdf (13.10.2017.).

18. Floress, M. T., Rader, R. A., Berlinghof, J. R. \& Fanok, P. C. (2018). Externalizing behaviors within general, at-risk, and special education preschool classrooms: A preliminary investigation. Preventing School Failure: Alternative Education for ChiIdren and Youth, 64 (2), 279-288. https://doi.org/10.1080/1045988x.2018.1443424

19. Fox, L. \& Hemmeter, M. L. (2009). A programwide model for supporting social emotional development and addressing challenging behavior in early childhood settings. In: Sailor, W., Dunlap, G. Sugai, G. \& Horner, R. (eds.), Handbook of positive behavior support. New York: Springer, 177-202. https://doi.org/10.1007/978-0387-09632-2_8

20. Fox, L. \& Swett, J. (2017). Implementing partnerships with families to promote the social and emotional competence of young children. In: Weist, M. D. Weist, S. A. Garbacz, K. L., Lane, D. \& Kincaid, D. (eds.), Aligning and integrating family engagement in positive behavioral interventions and supports (PBIS): Concepts and strategies for families and schools in key contexts. Center for Positive Behavioral Interventions and Supports. Eugene, Oregon: University of Oregon Press, 84-97.

21. Gettinger, M., Stoiber, K. \& Koscik, R. (2008). Effects of a preparation program focused on accommodating children with challenging behaviors. Teacher Education and Special Education, 31 (3), 164-181. https://doi.org/10.1177/0888406408330624

22. Glascoe, F.P. (2015). Evidence-based early detection of developmental-behavioral problems in primary care: What to expect and how to do it. Journal of Pediatric Health Care, 2946-53. https://doi.org/10.1016/j.pedhc.2014.06.005

23. Guest, G., MacQueen, K. M. \& Namey, E. E. (2012). Applied thematic analysis. Thousand Oaks, CA: Sage. https://doi.org/10.4135/9781483384436

\section{6 članci}


24. Hartas, D. (2011). Children's language and behavioural, social and emotional difficulties and prosocial behaviour during the toddler years and at school entry. British Journal of Special Education, 38 (2), 83-91. https://doi.org/10.1111/j.14678578.2011.00507.x

25. Horsburgh, D. (2003). Evaluation of qualitative research. Journal of Clinical Nursing. 12 (2), 307-312. https://doi.org/10.1046/j.1365-2702.2003.00683.x

26. Iorfino, F., Hermens, D. F., Cross, S., Zmicerevska, N., Nichles, A., Badcock, C. A., Groot, J., Scott, E. \& Hickie, I. (2018). Delineating the trajectories of social and occupational functioning of young people attending early intervention mental health services in Australia: A longitudinal study. BMJ Open, 8 (3), epage e020678, https:// doi.org/10.1136/bmjopen-2017-020678

27. Ivaštanin, I. \& Vrbanec, D. (2015). Razvijanje partnerstva s roditeljima. Dijete, vrtić, obitelj: Časopis za odgoj i naobrazbu predškolske djece namijenjen stručnjacima i roditeljima, $25,79$.

28. Jolivette, K. \& Steed, E. A. (2010). Classroom management strategies for young children with challenging behavior within early childhood settings. NHSA Dialog, 13 (3), 198-213. https://doi.org/10.1080/15240754.2010.492358

29. Jurčević-Lozančić, A. (2005). Izazovi odrastanja - predškolsko dijete u okružju suvremene obitelji i vrtića. Petrinja: Visoka učiteljska škola u Petrinji.

30. Jurčević-Lozančić, A. (2018). Socijalne kompetencije odgojitelja - primjenjujemo li suvremene spoznaje? Croatian Journal of Education - Hrvatski časopis za odgoj i obrazovanje, 20, 47-58. https://doi.org/10.15516/cje.v20i0.3055

31. Kardum, V., Dujmović, M. \& Kardum-Bošnjak, S. (2008). Some viewes on the education on the teacher in the future. Metodički obzori, 3 (1), 8 I-90.

32. Kirkhaug, B., Drugli, M. B., Mørch, W. T \& Handegård, B. H. (2012) Teacher report of children's problem behavior on the sutter-Eyberg student behavior inventory - Revised (SESBI-R) in a Norwegian sample of preschool and school children. Scandinavian Journal of Educational Research, 56 (2), 139-153. https://doi.org/10. 1080/00313831.2011.568672

33. Koller-Trbović, N. (1998). Pravovremeno otkrivanje poremećaja u ponašanju djece i mladeži i rano interveniranje. Kriminologija i socijalna integracija, 6 (1), 51-60.

34. Koller-Trbović, N. (2012). Sudjelovanje djece u procesu procjene potreba i planiranja intervencija: socijalnopedagoški pristup. Zaštita prava i interesa djece s problemima u ponašanju, Zbornik priopćenja sa stručnih skupova pravobraniteljice za djecu. Zagreb: Pravobranitelj za djecu.

35. Koller-Trbović, N., Mirosavljević, A.\& Jeđud Borić, I. (2017). Procjena potreba djece imladih s problemima u ponašanju - konceptualne i metodičke odrednice. Zagreb: Unicef. 
36. Koller-Trbović, N., Žižak, A. \& Jeđud Borić, I. (2011). Standardi za terminologiju, definiciju, kriterije i način praćenja pojave poremećaja u ponašanju djece i mladih. Zagreb: Povjerenstvo za prevenciju poremećaja u ponašanju djece i mladih Vlade Republike Hrvatske. Ministarstvo obitelji, branitelja i međugeneracijske solidarnosti RH.

37. Kraljić Babić, K. \& Vejmelka, L. (2015). Specifičnosti nasilja među djecom, prevencije i tretmana nasilnog ponašanja u predškolskoj dobi. Socijalne teme, 1 (2), 91-114.

38. Kruizinga, I. (2015). Early detection of emotional and behavioural problems in preschool children. Doctoral disertation. Rotterdam: Nederlands. Preuzeto s: http:// hdl.handle.net/1765/77784 (1.10.2018.)

39. Kuhar, A. \& Sindik, J. (2011). Povezanost emocionalne kompetencije s odgajateljskim radom. Naša škola, 57 (227), 89-114.

40. Lewis, J. \& Ritchie, J. (2003). Generalising from Qualitative Research. In:. Ritchie, J., Lewis, J. (eds.), Qualitative research practice- a guide for social social science students and researchers. London: Thousand oaks, New Delhi: Sage, 263-286.

41. Loeber, R., Farrington, D. P. \& Petechuk, D. (2003). Child delinquency: Early intervention and prevention U. S. Department of Justice Office of Programs Office of Juvenile Justice and Delinquency Prevention. Preuzeto s: https://www.ncjrs.gov/ pdffiles1/ojjdp/186162.pdf (14.10.2017.). https://doi.org/10.1037/e306292005-008

42. Male, D. (2003). Challenging behaviour: The perceptions of teachers of children and young people with severe learning disabilities. Journal of Research in Special Educational Needs, 3 (3), 162-171. https://doi.org/10.1111/1471-3802.00011

43. McCabe, L. A. \& Frede, E. C. (2007). Challenging behaviours and the role of preschool education. Preschool Policy Brief. National Institute for Earyl Education Reserach, 16, 1-12.

44. Milas, G. (2005). Istraživačke metode u psihologiji. Jastrebarsko: Slap.

45. Miljak, A. (2009). Življenje djece u vrtiću - Novi pristupi u shvaćanju, istraživanju i organiziranju odgojno-obrazovnog procesa u dječjim vrtićima. Zagreb: SM Naklada.

46. Ministarstvo znanosti, obrazovanja i sporta (2014). Nacionalni kurikulum za rani i predškolski odgoj i obrazovanje. Preuzeto s: http://www.azoo.hr/images/strucni2015/Nacionalni-kurikulum-za-rani-i-predskolski-odgoj-i-obrazovanje.pdf (14.10.2017.).

47. Novak, M., Mihić, J., Bašić, J. \& Nix, R. L. (2016). PATHS in Croatia: A school-based randomised-controlled trial of a social and emotional learning curriculum. International Journal of Psychology, 52 (2), 87-95. https://doi.org/10.1002/ijop.12262

48. Patton, M. Q. (2002). Two decades of developments in qualitative inquiry: A personal, experiential perspective. Qualitative Social Work: Research and Practice, 1 (3), 261-283. https://doi.org/10.1177/1473325002001003636

\section{8 članci}


49. Perry, J. \& Carroll, M. (2008). The role of impulsive behavior in drug abuse. Psychopharmacology, 200 (1), 1-26. https://doi.org/10.1007/s00213-008-1173-0

50. Reid, K., Littlefield, L. \& Hammond, S. W. (2008). Early intervention for preschoolers with behaviour problems: Preliminary findings for the exploring together preschool program. Australian e-Journal for the Advancement of Mental Health, 7 (1), 15-29. https://doi.org/10.5172/jamh.7.1.15

51. Roffey, S. (2005). Helping with behaviour: Establishing the positive and addressing the difficult in the early years. London i New York: Routledge. https://doi. org/10.4324/9780203087671

52. Sabriïc, J. (2017). Prevention and early detection of emotional and behavioral problems in childhood in pediatric primary care. Pediatria Integral, 21 (1), 8-14.

53. Shenasa, E. D., Paradis A. D., Dolan, S. L., Wilhelm, C. S. \& Buka, S. L. (2012). ChiIdhood impulsive behavior and problem gambling by adulthood: A 30-year prospective community-based study. Addiction, 107 (1), 160-168. https://doi. org/10.1111/j.1360-0443.2011.03571.x

54. Sindik, J. \& Karalić, Z. (2012). Razlike u odgajateljskoj kompetenciji u dvije susjedne države. Naša škola, 62 (232), 67-80.

55. Slee, J. (2003). Managing difficult behaviour in young children. Early Childhood Australia, 10 (3), 3-7.

56. Slunjski, E. (2015). Izvan okvira - kvalitativni iskoraci u shvaćanju i oblikovanju predškolskog kurikuluma. Zagreb: Element.

57. Teekavanich, S., Chantaratin, S., Sirisakpanit, S. \& Tarugsa, J. (2017). Prevalence and factors related to behavioral and emotional problems among preschool children in Bangkok, Thailand. Journal of the Medical Association of Thailand, 100 (2), 175-182.

58. Tatalović Vorkapić, S. (2015). How much personality is important in educational context? In: Orel, M. (ed.), International conference EDUvision 2015: »Modern approaches to teaching ocming generation«. EDUvision, Ljubljana, Slovenija, 7583. Preuzeto s: http://eduvision.si/Content/Docs/Zbornik\%20prispevkov\%20 EDUvision\%202015.pdf. (1.10.2018.).

59. Uğur, Ç, Yürümez, E, Yılmazer, Y . (2019). Emotional and behavioral problems in infants and preschool children: prevalence and sociodemographic risk factors. The European Research Journal, 5 (1), 134-141. https://doi.org/10.18621/ eurj.379887

60. Vlah, N. \& Ferić, M. (2017). The need for additional support for nursery school children and the reasons why it is not provided: A teachers' perspective. Napredak, 158 (4), 461-481.

61. Vlah, N. \& Tatalović Vorkapić, S. (2017). Trauma symptoms, perceived social support, emotional competence and self-esteem as predictors of behavioural 
styles used by future nursery school teachers in social conflicts. Psihologijske teme, 26 (2), 397-416. https://doi.org/10.31820/pt.26.2.7

62. Vlah, N., Štifter, S. \& Bijedić, M. (2014). Some aspects of the phenomenology of risk behavior at preschool age, Defektologija, 20 (2), 130-136.Vlah, N., Smojver-Ažić, S. \& Dorčić Martinac, T. (2017). Risk for behavioral problems in the early and pre-school age: proposal of assessment measure. U: Sekušak Galešev, S., Jeđud Borić, I., Hržica, G., Bradarić Jončić, S., Jandrić Nišević, A., Kuvač Kraljević, J., Martinec, R., Ricijaš, N. \& Wagner Jakab, A. (ur.), Edukacijsko-rehabilitacijski fakultet Sveučilišta u Zagrebu, ERFCON 2017-The 9th international conference of the Faculty of Education and Rehabilitation Sciences University of Zagreb, Zagreb, 17.-19.5.2017. Zagreb: Edukacijsko-rehabiltacijski fakultet, 193-194. Preuzeto s: http://www.conference.erf.unizg.hr/images/ERFCON_2017_Book_of_Abstracts. $\operatorname{pdf}(1.10 .2018$.$) .$

63. Vučković Juroš, T. (2011). Reporting on the issues of research rigour and ethics: The case of publications using qualitative methods in the Croatian social science journals. Revija za sociologiju, 41(2), 161-184. https://doi.org/10.5613/rzs.41.2.2

64. Walker, H. M., Ramsey, E. \& Gresham, F. M. (2004). Antisocial behavior in school: Evidenced-based practices (2nd edition). Belmont. CA: Wadsworth/Thomson Learning.

65. Whittaker, J. E. V. \& Harden, B. J. (2010.). Beyond ABCs and 123s: Enhancing teacher- child relationship quality to promote children's behavioral development. NHSA Dialog, 13 (3), 185-191. https://doi.org/10.1080/15240754.2010.493472

66. Williford, A. P., LoCasale-Crouch, J., Whittaker, J. V., DeCoster, J., Hartz, K. A., Carter, L. M., Sanger Wolcott, C. \& Hatfield, B. E. (2017). Changing teacher-child dyadic intweractions to improve preschool children's externalising behaviors. Child Development, 88 (5), 1544-1553. https://doi.org/10.1111/cdev.12703

67. Zwönitzer, A., Ziegenhain, U., Pillhofer, M., Fegert, J., Künster, A., Bovenschen, I. \& Kindler, H. (2016). Early intervention and cognitive development: A longitudinal study with psychologically stressed mother-child-dyad during early childhood. Praxis Der Kinderpsychologie Und Kinderpsychiatrie, 65 (5), 340-353.

68. Žižak, A. (1997). Elementi profesionalne kompetentnosti socijalnih pedagoga. Kriminologija i socijalna integracija, 1-2, 1-11. 
N. Vlah, A. Mirosavljević, V. Katić: Nošenje odgajatelja predškolskih ustanova s rizičnim ponašanjima...

Nataša Vlah

University of Rijeka

Faculty of Teacher Education

Anja Mirosavljević

University of Zagreb

Faculty of Education and Rehabilitation Sciences

Vesna Katić

University of Rijeka

Faculty of Teacher Education Rijeka

\section{HOW PRESCHOOL TEACHERS ADDRESS RISK BEHAVIOURS IN CHILDREN}

\section{ABSTRACT}

Risk behaviours at preschool age are among the strongest predictors for later behavioural problems. Preschool age is therefore crucial for prevention and early intervention. In this context, kindergartens are particularly important, and competent preschool teachers implementing numerous activities with children, including those exhibiting risky behaviours, are an important element of protection.

The paper reports on the results of a qualitative analysis of focus groups consisting of preschool teachers from the kindergarten Rijeka, who shared their views of competences and strategies for working with such children, as well as of the difficulties arising on a daily basis in the work with children engaging in risk behaviours. Thematic analysis according to Clarke and Braun (2013) has been applied for this purpose, highlighting three topics: „Factors contributing to appropriately addressing risk behaviours in children «, »Factors contributing to ineffectively addressing risk behaviours in children«, and »Recommendations for improving work with children engaging in risky behaviouru.

There is a need for the implementation of prevention and early intervention programmes in kindergartens as well as for providing systematic and expert support to preschool teachers in their work with children engaging in risky behaviour.

Key words: preschool teachers, preschool children, risk behaviours, thematic analysis.

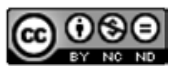

Međunarodna licenca / International License:

Creative Commons Attribution-NonCommercial-NoDerivatives 4.0. 
